International Journal of Linguistics, Literature and Culture
Available online at https://sloap.org/journals/index.php/ijllc/
Vol. 5, No. 6, November 2019, pages: 1227
ISSN: 2455-8028
https://doi.org/10.21744/ijllc.v5n6.747

\title{
Fundamentalist and Tolerant Islamic Discourse in John Updike's Terrorist and Jonathan Wright's Translation The Televangelist: A Corpus-based Critical Discourse Analysis of Semantic Prosody
}

Ahlam Ahmed Mohamed Othman a

Article history:

Received: 09 May 2019

Accepted: 31 July 2019

Published: 18 September 2019

\section{Keywords:}

corpus-based; critical discourse; islamic discourse; semantic prosody; terrorist;

\begin{abstract}
Corpus-based critical discourse analysis studies have gained momentum in the last decade. Corpus Linguistics allowed critical discourse analysts to avoid bias in data selection and enlarge their samples for more representative findings. Critical Discourse Analysis, on the other hand, gave depth to corpus linguistic analysis by contextualizing it. The present study combines the two approaches to analyze the semantic prosody of Islamic keywords common to John Updike's Terrorist published in 2006 and Jonathan Wright's translation The Televangelist published in 2016. The results of corpus-based analysis show that while the semantic prosody of Islamic keywords is negative in Updike's novel, it is highly positive in the translated novel. The conclusion is that Van Dijk's proposition of the polarized representation of 'us' versus 'them' holds for Updike's fundamentalist Islamic discourse which negatively represents Islam and Muslims. However, Van Dijk's proposition holds only partially for Wright's tolerant Islamic discourse which positively represents Islam and Muslims without misrepresenting the other.
\end{abstract}

2455-8028 ${ }^{\circ}$ Copyright 2019. The Author. This is an open-access article under the CC BY-SA license (https://creativecommons.org/licenses/by-sa/4.0/) All rights reserved.

\section{Author correspondence:}

Ahlam Ahmed Mohamed Othman,

Associate Professor of English Literature \& Quality Assurance Unit Director

Faculty of Arts and Humanities, The British University in Egypt (BUE)

El Sherouk City, Cairo - Suez Desert Road, Egypt

Postal No. 11837 - P.O. Box 43, Tel: (+202) 26890000 Ext: 1721.

Email address: ahlam.othman@bue.edu.eg

a The British University in Egypt (BUE), Cairo, Egypt 


\section{Introduction}

Corpus-based critical discourse analysis studies have gained momentum in the last decade thanks to the increasing numbers of corpora and concordance software. Corpus Linguistics (CL) allowed critical discourse analysts to avoid bias in data selection and enlarge their samples for more representative findings. Critical Discourse Analysis, on the other hand, gave depth to corpus linguistic analysis by contextualizing it because CDA is concerned with the investigation of how language reflects social practice and highlights "the underlying ideologies that play a role in the reproduction of or resistance against dominance or inequality” (Van Dijk, 1995). As Wodak \& Meyer (2009), note, $\mathrm{CDA}$ is "fundamentally interested in analyzing opaque as well as transparent structural relationships of dominance, discrimination, power and control as manifested in language" (10), and "identifying and defining social, economic and historical power relations between dominant and subordinate groups" (Henry \& Tator, 2002) with the aim of deconstructing such hegemonic relations \& ideologies.

Using corpus-based critical discourse analysis, the present study aims at comparing Islamic discourse in two novels written after 9/11: the first is John Updike's Terrorist (2006); the second is Jonathan Wright's The Televangelist (2016), the translation of Ibrahim Essa's Arabic novel Mawlana (2012). Updike (1932-2009) is a wellknown American novelist, poet, short-story writer, and literary critic. Winner the Pulitzer Prize for Fiction more than once, Updike published more than twenty novels, more than a dozen short-story collections, as well as poetry, art and literary criticism. Terrorist is Updike's twenty second novel. It tells the story of Ahmed born of an American Catholic mother, Teresa, and an Egyptian Muslim father, Ashmawy. Rejecting his mother's dissolute life and Americans' materialism and sexual freedom, Ahmed turns, in the absence of his father, to the fundamentalist Muslim Sheikh Rashid for guidance. Under the influence of that sheikh, Ahmed becomes a truck driver rather than going to college. Having been brainwashed by Sheikh Rashid, Ahmed agrees to drive his truck into the tunnel and blow himself up to kill infidels. Fortunately, he is dissuaded from this terrorist act by Jack Levy, his Jewish guidance counsellor. As for Jonathan Wright, he was the Reuters bureau chief in Cairo and translated Alaa Al-Aswany, Youssef Ziedan, and Hassan Blassim. Wright won the Independent Foreign Fiction Prize and the Saif GhobashBanipal Prize for Arabic Literary Translation. The Televangelist, translated from Essa's Arabic novel Mawlana which was shortlisted for the 2013 International Prize for Arabic Fiction, tells the story of Sheikh Hatem, imam of Sultan Hassan Mosque, who becomes a famous TV preacher and is entrusted with the task of persuading Hassan, brother-in- law of the president's son, to re-embrace Islam having converted to Christianity. Sheikh Hatem finds out that Hassan is not a fervent convert to Christianity, but is confused and in need of affection. At the end of the novel, however, the reader discovers that Hassan is a terrorist who has been pretending to be a Christian convert only to bomb the church. The two novels therefore have similar plots and protagonists but two different endings. More importantly, they are characterized by their Islamic discourse that involves the use of a number of common keywords that reflect the writers' attitude toward Islam. To uncover this attitude the present study uses Critical Discourse Analysis. It might be argued that CDA is not a traditional tool of literary analysis; however, as Van Dijk (2001), emphasizes,

CDA is not a direction of research among others, like TG grammar, or systemic linguistics, nor a subdiscipline of discourse analysis such as the psychology of discourse or conversation analysis. It is not a method, nor a theory that simply can be applied to social problems. CDA can be conducted in, and combined with any approach and subdiscipline in the humanities and the social sciences ... CDA is a critical perspective on doing scholarship: it is, so to speak, discourse analysis 'with an attitude'. It focuses on social problems, and especially on the role of discourse in the production and reproduction of power abuse or domination. (96)

\section{Literature Review}

According to a survey conducted by Mark Nartey \& Isaac N. Mwinlaaru (2019), studies that set the stage for the integration of CL and CDA include Hardt-Mautner (1995); Morrison \& Love (1996); Flowerdew (1997); Sotillo \& Starace-Nastasi (1999); Simon-Vandenbergen (2000); and Downs (2002). These studies drew on small corpora and focused on the analysis of frequencies and key-word-in-context (KWIC) Concordances. It is Baker et al., (2008), however, that marked a turn in the development of corpus-based CDA studies drawing on a large corpus of 140 million words that included the discourse of refugees, asylum seekers, immigrants and migrants in the UK press from 1996 to 2005. In addition to wordlist and concordance analyses, Baker et al., (2008), used other corpus methods including the analysis of colligations and collocations, keywords/key cluster analysis, semantic preference, semantic prosody and/or discourse prosody, normed vs. raw frequencies, dispersion plot as well as lemmatization and standardization. Studies that followed the eclectic approach of Baker et al., (2008); Nartey \& Mwinlaaru (2019) 
maintain, include KhosraviNik (2008); Mulderrig (2008); O’ Halloran (2008); Taylor (2009); Prentice \& Hardie (2009); Augoustinos et al., (2010), Freake et al., (2011), and Subtirelu (2013).

During the third phase (2011 - 2016), Nartey \& Mwinlaaru (2019) remark, corpus-based CDA studies departed from Baker et al., (2008), by drawing on a bilingual and/or comparative corpus (e.g. Freake et al., 2011; Jaworska \& Krishnamurthy, 2012), examining key function/grammatical words (e.g. Pearce, 2014), and using other analytical models and/or theories; for example, functional theory (El-Falaky, 2015; Lee, 2016; Lindayana et al., 2018), translation theory (Murphy, 2013), social theory (Mulderrig, 2008; 2011), critical stylistics (Jeffries \& Evans, 2013), contrastive analysis (Schroter \& Storjohann, 2015), sociolinguistics (Chiluwa, 2012), critical literacy pedagogy (Abid \& Manan, 2015), multimodality (Edwards \& Milani, 2014), topic modeling (Tornberg \& Tornberg, 2016; Iswanto et al., 2018; Jurgaitis, 2018), pragmatics (Triebl, 2015), genre theory (Skalicky, 2013), theory of governmentality (MacDonald \& Hunter, 2013) and theory of argumentation (Lippi \& Torroni, 2016; Azhari et al., 2018). Nevertheless, as Nartey \& Mwinlaaru (2019) note, "It seems ... that the main aim of many studies in combining corpus methods and CDA is to arrive at more accurate, insightful, objective, and generalizable findings rather than contributing to a specific discourse-oriented theory" (11).

Ten domains were identified by Nartey \& Mwinlaaru (2019), in the database of studies integrating corpus linguistic methods with CDA: business and administration, education, healthcare, history, law, media, media and politics, politics, religion and culture, and social media. From the database, seven key issues have received special attention: gender $(13,10.7 \%)$, identity $(4,3.3 \%)$, ideology and power $(73,60.3 \%)$, immigration $(8,6.6 \%)$, Islam and race $(8,6.6 \%)$, nationalism $(4,3.3 \%)$ as well as war and security $(3,2.5 \%)$. The findings of Nartey \& Mwinlaaru (2019), show that politics and media are the most represented domains and that ideology and power $(73,60.3 \%)$ is the dominant topic of coverage, thus reinforcing the principal thesis underlying CDA. While this is the case, Nartey \& Mwinlaaru (2019), recommend venturing into other domains such as religion and culture to study such hot issues as terrorism using corpus-based CDA and create critical awareness.

Following September 11, "Islamic terrorism" has emerged as one of the most ubiquitous discourses in the modern era. Jackson (2007), traces the origin of the current discourse of "Islamic terrorism" to studies of "religious terrorism," a subject founded by David Rapoport's seminal article "Fear and Trembling: Terrorism in Three Religious Traditions" published in 1984. Jackson (2007), maintains that the assumptions, labels and narratives of this discourse were driven from the work of such orientalist Middle East scholars as Bernard Lewis, Noah Feldman and the late Raphael Patai. However, it is Samuel Huntington's influential essay "The Clash of Civilizations" (1993) that is considered the antecedent of the current "Islamic terrorism" discourse.

Among the most prominent approaches to CDA is Van Dijk's socio-cognitive approach which focuses on social cognitions "socially shared representations of societal arrangements, groups and relations, as well as mental operations such as interpretation, thinking and arguing, inferencing and learning" (Van Dijk, 1993). He argues that "groups have (more or less) power if they are able to (more or less) control the acts and minds of (members of) other groups" (Van Dijk, 2003). He explains that groups exercise control over others through a strategy of positive selfpresentation and negative other-presentation. Van Dijk's studies, therefore, focus on the ideological dimension of "Us" versus "them" and highlight the discursive strategies used to exercise dominant control.

In "Multidisciplinary CDA: A Plea for Diversity" (2001), Van Dijk recommends that the analysis of a large text start with the "semantic macrostructure;" that is, the topics or global meanings that are often expressed in the title, summary, thematic sentences or conclusions. Next, local meanings such as "the meaning of words (a study that also may be called lexical, depending on one's perspective), the structures of propositions, and coherence and other relations between propositions" (Van Dijk, 2001) should be studied.

One of the local meanings to analyze and compare in literary discourse is that of semantic prosody. Coined by Louw (1993), from the Firthian term that refers to phonological colouring, semantic prosody is defined as "a consistent aura of meaning with which a form is imbued by its collocates" (157). Louw (1993), studied a number of lexical items such as the adverb utterly, the phrase bent on and the expression symptomatic of, and found that they all have a negative semantic prosody because they are followed by nodes that have a negative meaning such as destroying, ruining, depression, etc. Louw (1993), uses the phrase set in as an example of the connection between a lexical item and its collocates, which he calls colouring. When a lexical item consistently has collocates belonging to a certain semantic field, it is coloured by its collocates. Such semantic consistency may be already established as in the case of the phrasal verb set in, or it can be built up by an author to convey a certain attitude. In her MA thesis, Semantic Prosody in Literary Analysis: A Corpus-based Stylistic Study of H. P. Lovecraft's stories, Hannah Spencer argues that "an author or narrator may choose to build up their own unique semantic prosody around a lexical item to convey an attitude" (Fitri et al., 2018; Kawangung, 2019).

Othman, A. A. M. (2019). Fundamentalist and tolerant islamic discourse in john updike's terrorist and jonathan wright's translation the televangelist: a corpus-based critical discourse analysis of semantic prosody. International Journal of Linguistics, Literature and Culture, 5(6), 1-27. https://doi.org/10.21744/ijllc.v5n6.747 
Although Louw notes the inseparability of form and meaning, his definition does not refer to the function of semantic prosody or its pragmatic aspect. John Sinclair (1996), on the other hand, points out that semantic prosodies are "attitudinal and on the pragmatic side of the semantics-pragmatics continuum" (87). Semantic/discourse prosodies can help create a topos or "a line of argument;" that is, they can lead the reader from premise to conclusion without explicit argumentation. Sinclair, therefore, recommends exploring a broader 'unit of meaning' than two nodes to the left or right of the node in order to reach conclusions within a synchronic framework.

Hunston (2007), argues that describing semantic prosody as positive, negative or neutral is an oversimplification because there are instances where it can be described as frustrating or surprising. Hunston (2007), discusses two types of semantic consistency: “(a) consistent co-occurrence of (types of) linguistic items (Partington, 2004) or (b) consistency in the discourse function of a sequence of such items (Sinclair, 2004; Prasetyo, 2017; Suyanu et al., 2017)" (251). For example, Hunston (2007), examines the verb cause and finds that it has a negative semantic prosody if human self-interest is involved; however, this is not the case in a scientific register where human selfinterest is not evaluated. Thus, she concludes that a node does not necessarily have the same semantic prosody in every context.

In so far as the identification of the semantic prosody of a lexical item is concerned, the present study is corpusbased. In the analysis, however, Van Dijk's approach to CDA is adopted to compare Islamic discourse in Updike's Terrorist (2006) and Wright's The Televangelist (2016). Being a corpus-based CDA study of fiction, it attempts at answering the following questions: is there any difference between the two novels in terms of Islamic discourse? Does Van Dijk's proposition of the polarized representation of 'us' versus 'them' hold for the two novels? How do the two novelists build up semantic consistency to convey their attitude towards Islam?

\section{Materials and Methods}

\section{Methodology}

In order to identify keywords in each novel, the 100-million-word British National Corpus (BNC) was used as a reference corpus because, as Mike Scott recommends in Archer's What's in a Word List (2009), it contains several different genres and texts of varying lengths. Using Sketch Engine, the BNC Word list was generated, then AntConc was used to compare each novel to the reference word list and generate keyword lists. A $p$-value of 0.0001 was set, which indicates a 99.99 percent confidence that the outcome of the keyword analysis is not due to chance. This cutoff point is reasonable given the size of the two corpora under study: The Televangelist (900459 words); Terrorist (540015 words). Once the two keyword lists were generated, common content keywords were identified and classified into "fictional world signals," keywords that relate to concrete characters and objects, and "thematic signals," keywords that require interpretation, following Mahlberg \& McIntyre's (2011) model. Fictional world keywords like television in The Televangelist and truck in Terrorist were not chosen for analysis because they refer to concrete objects and do not belong to Islamic discourse. Only commonly used thematic signal keywords; that is, keywords that require interpretation and are related to Islamic discourse, were selected for analysis (See Appendix A). KWIC searches of these thematic signal keywords were conducted using AntConc. In Contextual Prosodic Theory: Bringing Semantic Prosodies to Life, Louw (2000), notes that: "Most semantic prosodies accumulate and concentrate their power within the nine-node window of acknowledged collocational force" (4). Accordingly, four nodes on each side of the keyword were examined to identify the unique semantic prosody built up by Updike and Wright around these keywords.

\section{Data Analysis}

The analysis of commonly used thematic world keywords that are related to Islamic discourse (God, faith, believe, un/believers, religion, Islam, prophet, Qur'an, sheikh, imam, preacher, mosque, prayer, Muslims, Christians, convert, woman/ women) will run as follows: sample concordance lines resulting from KWIC searches in both novels will be analyzed to find out how each writer creates his own semantic prosody that reflects his attitude. In Terrorist, for example, Updike creates a negative semantic prosody for the keyword God is evident from the following concordance lines: 


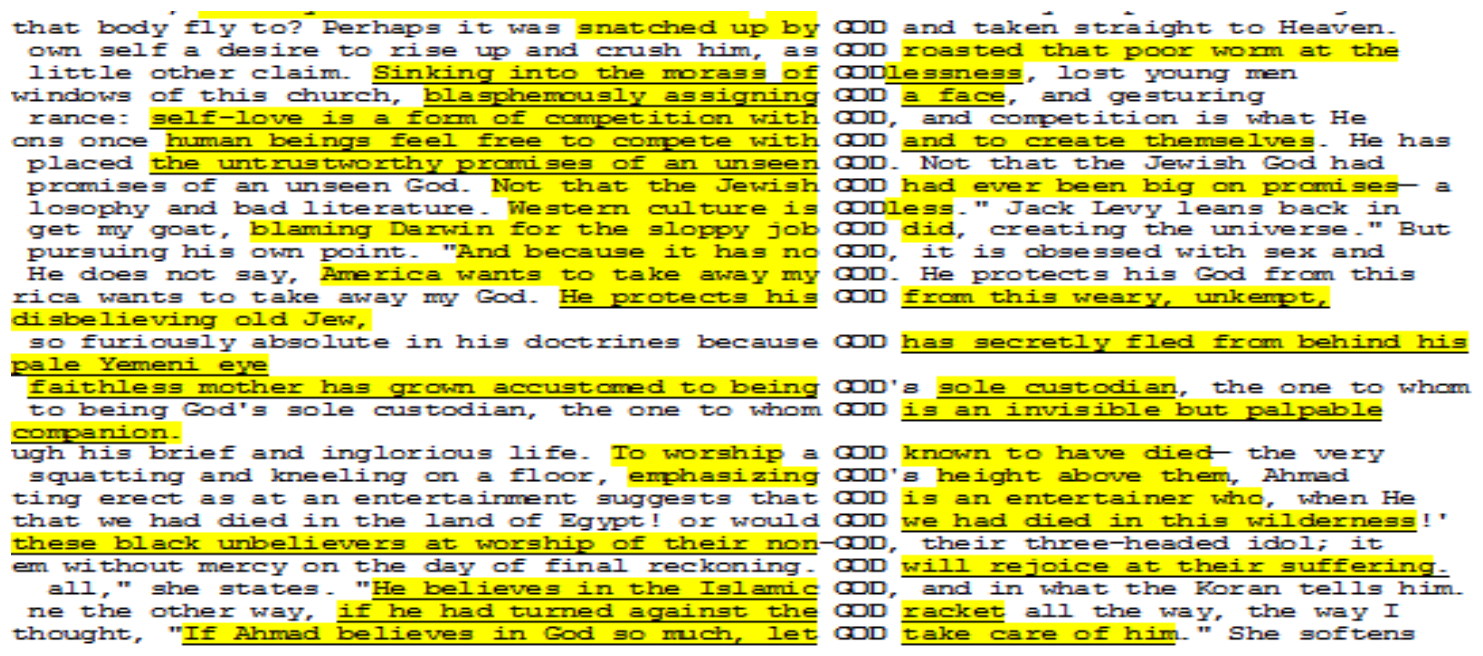

Figure 1. God in Updike's Terrorist

God here co-occurs with such blasphemous nodes as: -lessness, -like men, sinking into the morass of, blasphemously assigning a face, compete with, to create themselves, untrustworthy promises of an unseen, big on promises, sloppy job. This negative semantic prosody is created in the novel by fundamentalists who view Western culture as Godless. By creating this negative attitude towards Western culture, fundamentalists are able to exercise control over others. Thus Shaikh Rashid succeeds in making Ahmed become a truck driver rather than go to college to study academic subjects and assimilate into a culture that is determined to "take away" his God. Echoing his imam, Ahmed says: "Western culture is Godless. ... And because it has no God, it is obsessed with sex and luxury goods" (38).

In Wright's The Televangelist, however, the keyword God has a highly positive semantic prosody whether it appears in the context of prayer and invocation or in the context of worship and glorification as in the following concordance lines:

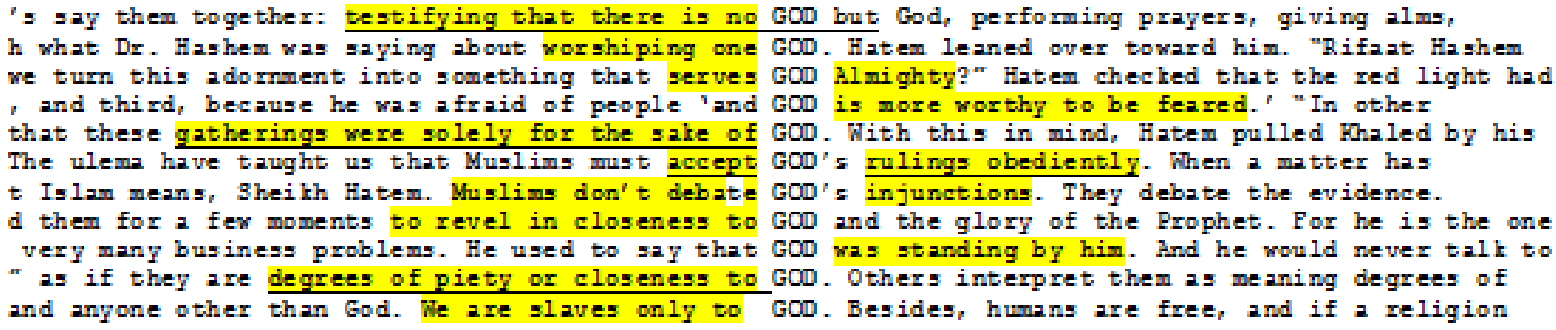

\section{Figure 2. God in Wright's Televangelist}

In this tolerant Islamic discourse, the keyword God co-occurs with such positive expressions as worshipping one, serves, Almighty, more worthy to be feared, gatherings were solely for the sake of, accept rulings obediently, Muslims don't debate injunctions, revel in closeness to, was standing by him, degrees of piety and closeness to, we are slaves only to. Rather than evaluating other cultures or religions, there is an emphasis on worshipping and fearing God. This is significant because tolerant Islamic discourse, in contrast to the fundamentalist one, has no targets other than calling for the worship of one God. In the context of prayer and invocation too, the keyword God co-occurs with positive expressions such as bless you, the blessings of, the grace of, mercy of, pleased with, bring you good news, bless you and preserve you as appears from the following concordance lines.

Othman, A. A. M. (2019). Fundamentalist and tolerant islamic discourse in john updike's terrorist and jonathan wright's translation the televangelist: a corpus-based critical discourse analysis of semantic prosody. International Journal of Linguistics, Literature and Culture, 5(6), 1-27. https://doi.org/10.21744/ijllc.v5n6.747 
Marlana," she said, looking to him for approval. "GOD bless you, Georgette," he replied with a

he said. "Peace be upon $y$ ou and the blessings of GOD. Welcome to a new installment of our program.

for a start what your Prophet did. Muhamad, may GOD bless him and grant him peace, and I ash mercy

bless him and grant him peace, and I ask mercy of GOD, looked at the wife of his neighbor and his

the Prophet's marriage to Zeinab bint Jahsh, may GOD be pleased with her." Anwar realired that

ld! You said to one who had received the grace of GOD and your favor: 'Reep your wife, and fear God.'

$g$ to win the elections by a margin of three. "May GOD bring you good news, Mawlana," Khaled said

him. "That would bring me a thousand blessings." "GOD bless you and preserve 7 ou,"

\section{Figure 3. God in Wright's Televangelist}

In Updike's Terrorist, the keyword faith has a negative semantic prosody as appears from the following concordance lines:

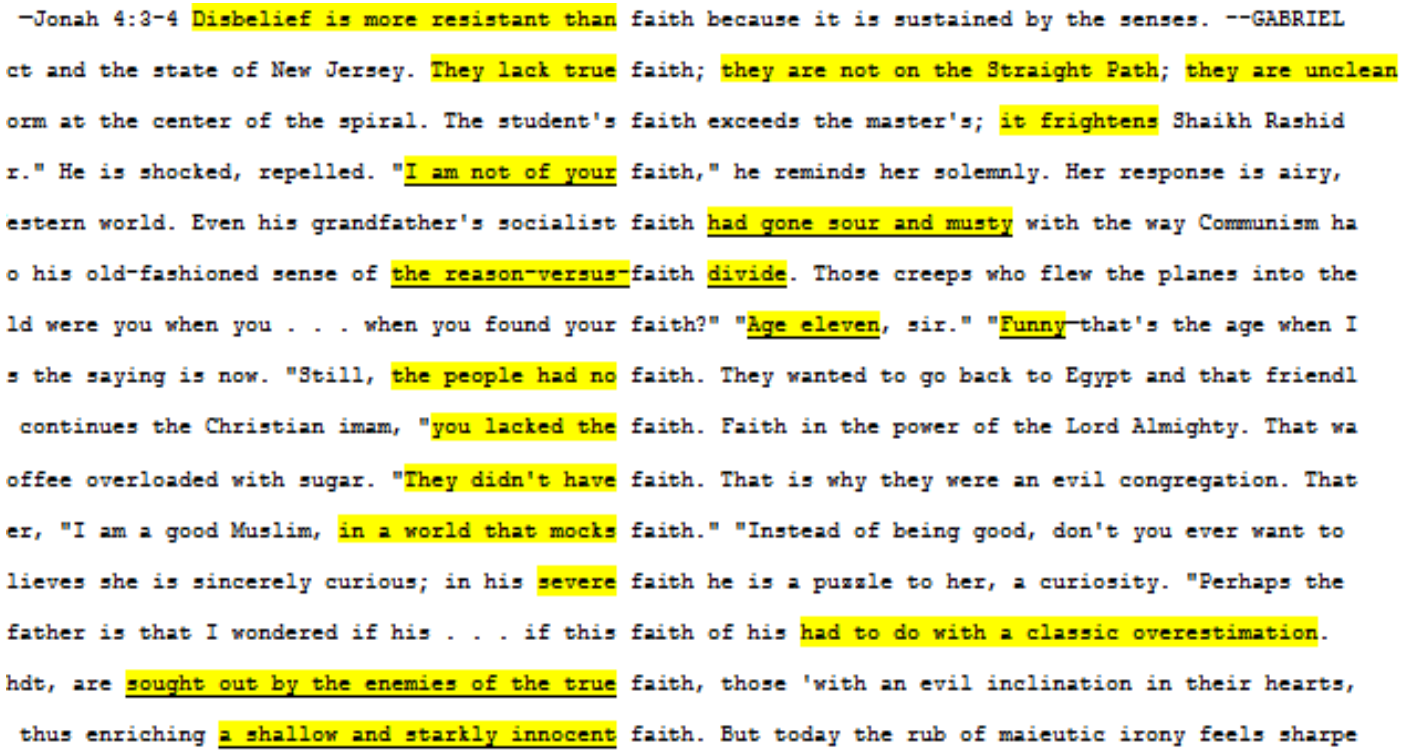

\section{Figure 4. Faith in Updike's Terrorist}

Faith co-occurs with: disbelief is more resistant than, lack true, they are not on the Straight Path, they are unclean, it frightens, I am not of your, had gone sour and musty, divide, funny, the people had no, you lacked the, they didn't have, a world that mocks, severe, a puzzle, a curiosity, the enemies of the true, a shallow and starkly innocent. Fundamentalists, like Shaikh Rashid, regard people who believe in other religions as unclean enemies who lack true faith. Again this negative attitude is created by fundamentalists to control vulnerable youth, like Ahmed, and drive them to do terrorist acts against those whom they view as enemies. It is not a coincidence, therefore, to find the keyword unbelievers more frequently used than believers in such a fundamentalist Islamic discourse. Fundamentalists regard followers of other religions as insects that need to be crushed and destroyed altogether. This is clear from the negative semantic prosody of the keyword unbelievers in the following concordance lines: 


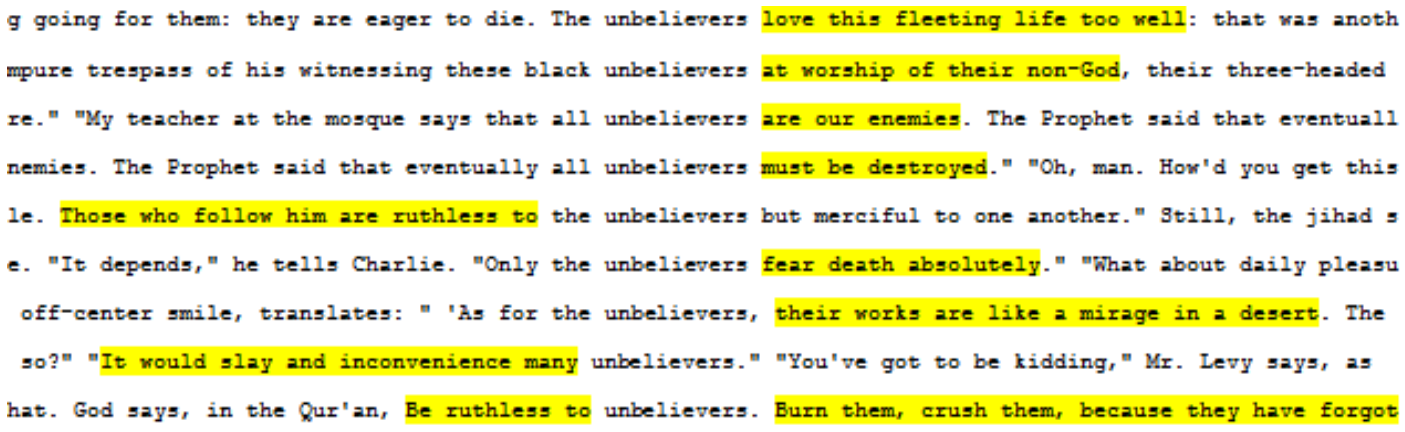

Figure 5. Unbelievers in Updike's Terrorist

Although faith is not a strong keyword in Wright's The Televangelist, it has a positive semantic prosody:

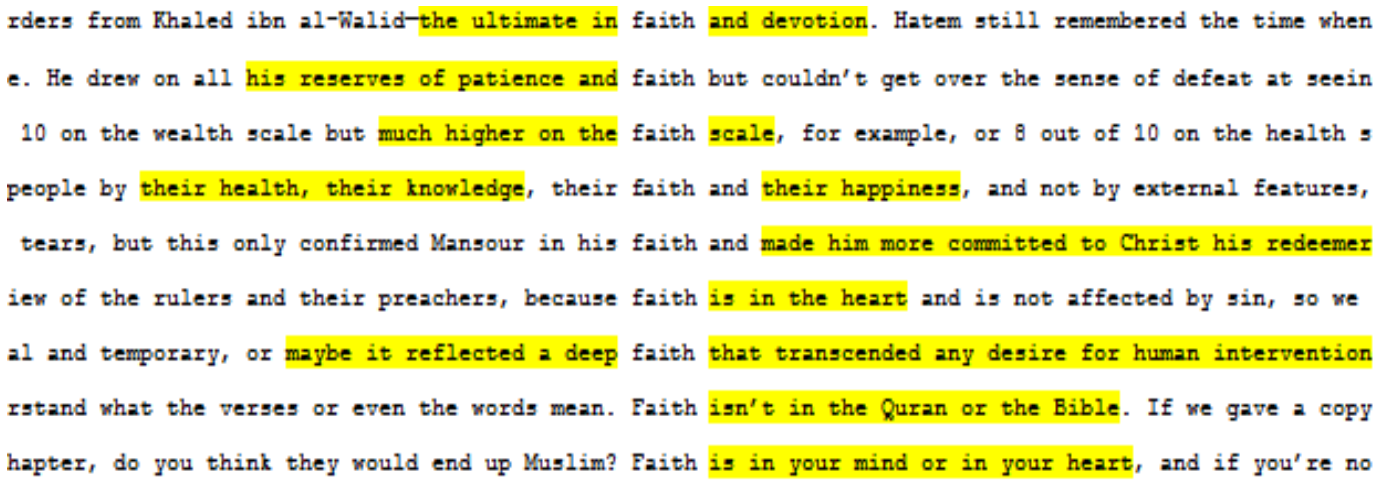

Figure 6. Faith in Wright's Televangelist

Faith co-occurs with the ultimate, devotion, his reserves of patience, much higher, their health, their knowledge, and their happiness, made him committed to Christ his redeemer, is in the heart, reflected a deep, transcended any desire for human intervention, isn't in the Qur'an or the Bible, is in your mind or in your heart. Tolerant Islamic discourse emphasizes faith is in the heart or mind, not in books of religion. It calls for accepting others because, as mentionedabove, it has no other agendas: it does not aim at misrepresenting others to gain any worldly power. It is also worth mentioning that the keyword believers in this tolerant Islamic discourse is more frequent than unbelievers and has a positive semantic prosody as in the following concordance lines:

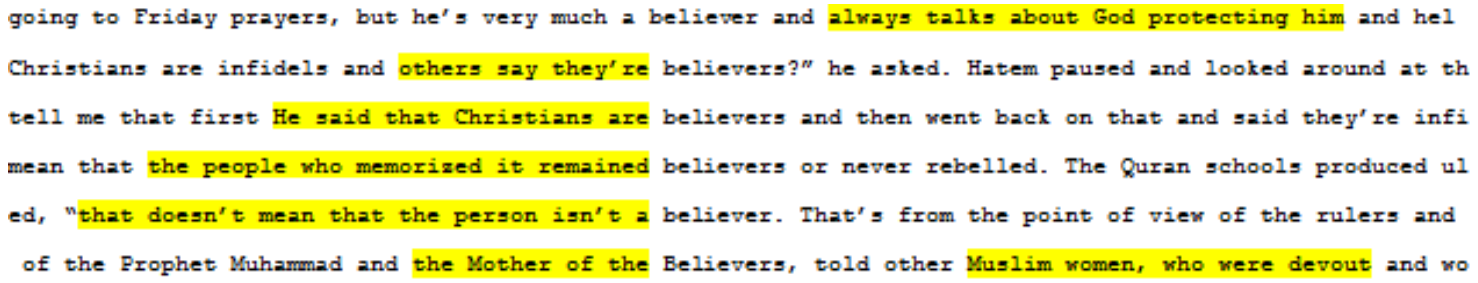

\section{Figure 7. Believers in Wright's Televangelist}

Similarly, the keyword believe has a positive semantic prosody. It co-occurs with in equal citizenship for everyone, in the church, in Christ and love Him, in Christ and in all the prophets, God in His glory and His greatness, Whoever wants to, let him, and whoever wants not to, let him not, in God and in what has been revealed to you, in God and the Last Day, those who follow Jesus are above those who don't, that the light of the Virgin Mary has come to me, in the light of the Virgin as well as Christians, is the Prophet of God, in him as Muslims.

Othman, A. A. M. (2019). Fundamentalist and tolerant islamic discourse in john updike's terrorist and jonathan wright's translation the televangelist: a corpus-based critical discourse analysis of semantic prosody. International Journal of Linguistics, Literature and Culture, 5(6), 1-27. https://doi.org/10.21744/ijllc.v5n6.747 


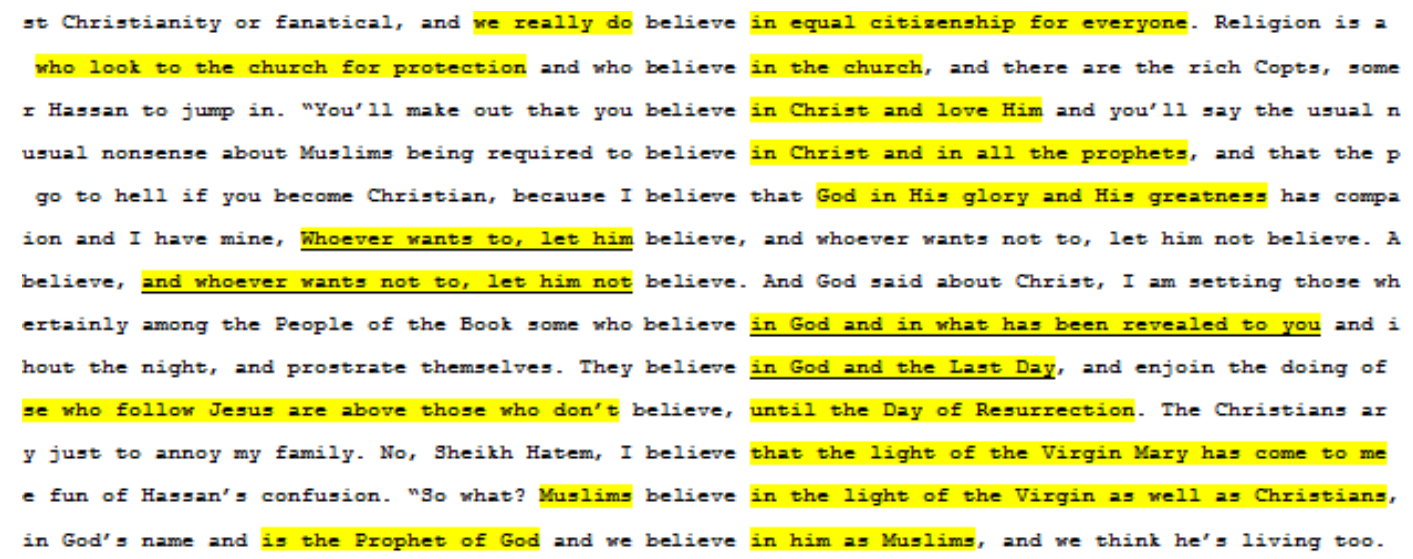

Figure 8. Believe in Wright's Televangelist

Unlike fundamentalist Islamic discourse that regards followers of other religions as unbelievers who should be crushed, tolerant Islamic discourse preaches love and equality, respects Christians, and stresses that to be a true believer, one needs to believe in all prophets.

Although religion is not a strong keyword in Updike's Terrorist, it has a negative semantic prosody: It co-occurs with don't take seriously, their dishevelled, disrespect, the wrong one, grotesquely mistaken and corrupt, had shed all, a relativistic approach that trivializes, doesn't take all that seriously, a ridiculous new, hated, a victim of the American, evil, blamed for the world's misery, images now attract hatred, and meant nothing to him.

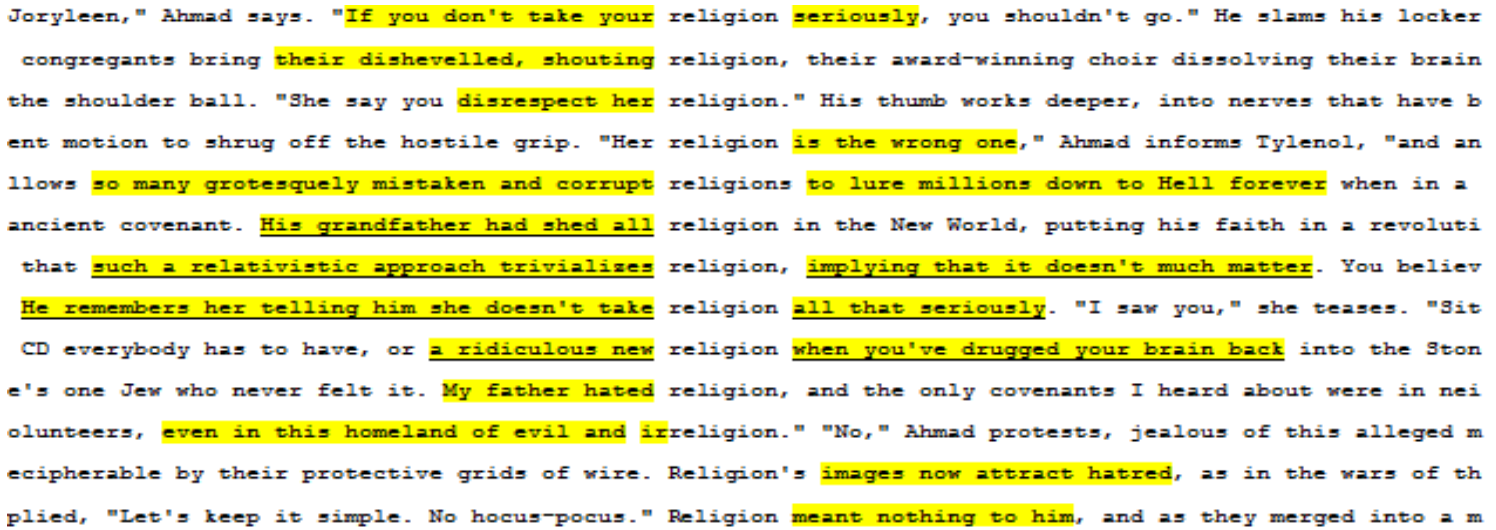

\section{Figure 9. Religion in Updike's Terrorist}

Fundamentalists have influenced Ahmed in a way that made him view those who are not Muslims as irreligious or at best not taking religion seriously. He tells his friend Jorlyeen: "All America wants of its citizens, your President has said, is for us to buy - to spend money we cannot afford and thus propel the economy forward for himself and other rich men" (72). This negative attitude drives Ahmed to isolate himself rather than assimilate into a culture that preaches sexual freedom, materialism and consumerism.

In Wright's Televangelist, on the other hand, religion is a very strong keyword, ranking number 20 and occuring 163 times with 3597.7 keynness compared to the BNC. However, its semantic prosody differs according to the context. For example, when Sheikh Hatem, the televangelist, is having a debate about religion with Hassan, the alleged Christian convert, the keyword has a positive semantic prosody as appears from the following concordance lines: 
it, but what exactly does He say? 'Where God is, RELIGION is Islan.' Where who is? Where God is. That's whe but here on earth He Himself says, You have your RELIGION and I have nine, Whoever wants to, let him believ of the Quran, Be says, There is no compulsion in RELIGIOS, and He says, 0 children of Israel, remember the ost," he said. "Accepted where? In this world all RELIGIONs are velcone," Haten replied. "In the Bereafter 6 ing but Islam, but what will he do with the other RELIGIONs? We don't know. Perhaps some religions will have the other religions? We don't know. Perhaps some RELIGIONs will have privileges over other religions. In th en go ahead, be a Christian, or choose some other RELIGION, never mind? Of course promoting a religion means other religion, never mind? Of course pronoting a RELIGION means saying 'My religion is the best, better tha ? Of course promoting a religion means saying 'MY RELIGION is the best, better than the others.' Anywa, Chr others.' Anymy, Christianity says it's the best RELIGION, and that's its right and quite natural. In fact atural. In fact it says there's basically no such RELIGION as Islam, and if you fault Islam for being arroga tiring and it makes you tense, and looking for a RELIGION is sonething that requires deep study and conpari re's a bach-and-forth interaction between you and RELIGION. It evolves inside you as you make adjustaents so ly master all the details or even the basics of a RELIGION. Now as for me, I don't represent Islan, of cours Figure 10. Religion in Wright's Televangelist

Tolerant Islamic discourse stresses that there is no compulsion in religion: that people are free to choose whatever religion they like. When, however, the keyword is used in the context of describing men of religion, it has a negative semantic prosody as appears from the following concordance lines:

7 were the hind of people who wanted a version of RELIGION that would serve their worldly aspirations and an preachers who didn't look like sheiths, who took RELIGION into the world of adolescents and xomen, and wo father in mowing how to strike a balance between ReLIGION and personal interests, and so he didn't speal mu d. "The problen is that if the sheiths simplified RELIGION, they'd be out of a job," he said. "They live by id Haten. "Personally I've made more money out of RELIGIOS than any of the early caliphs made, or Buthari or 5 influence. When they stopped acting like aen of RELIGION, they lost their prestige and credibility in the focused on formalities and superficial aspects of ReLIGION. It was remarhable the way she objected to any to Figure 11. Religion in Wright's Televangelist

Thus there is a clear distinction between religion and the behavior of some men of religion who use it to serve their own purposes. In other words, tolerant Islamic discourse emphasizes that one should not devalue any religion based on the behaviour of its followers or scholars.

In Updike's Terrorist, the keyword Islam has a negative semantic prosody as appears from the following concordance lines: It co-occurs with nodes like coming after, ridicules, meant nothing, less than nothing, ends at the mosque, apostate adherents, anciently afflicted, anti-, a lazy matter of ethnic identity, less a faith, a filigreed doorway into the supernatural, a facet of their condition as an underclass, alien in a nation, chastise, under surveillance, pressure each other with, slay and inconvenience many unbelievers.

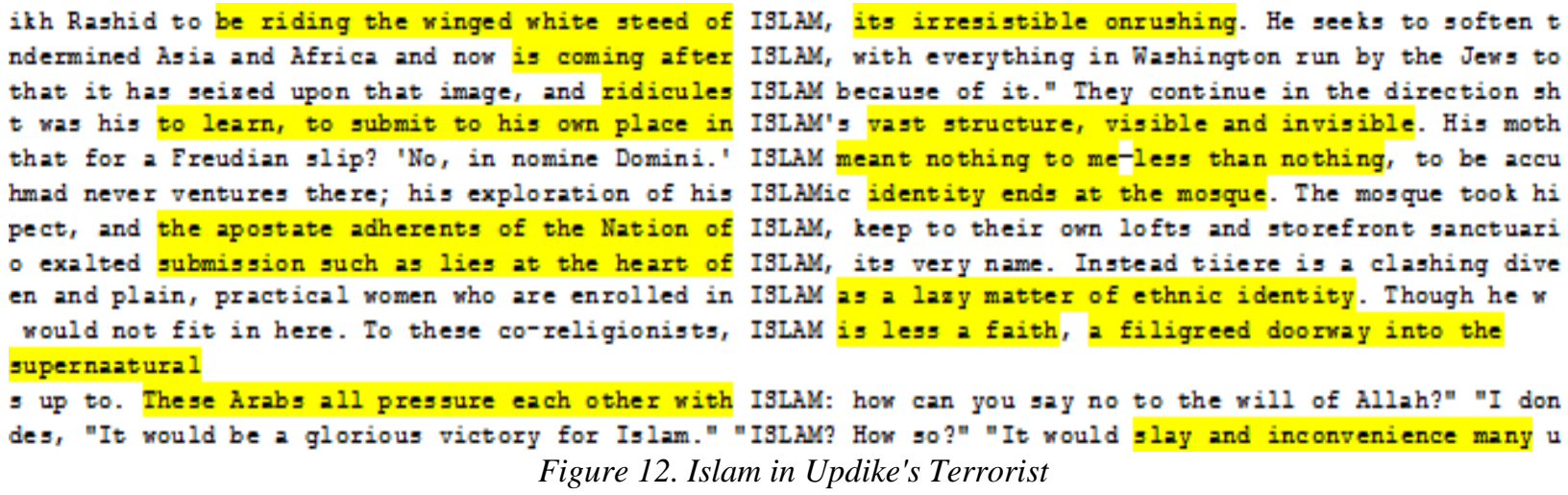

Updike's anti-Islamic discourse is typical of most post 9/11 Western fiction. As Hartnell argues, despite Updike's “apparently genuine attempt to displace reductive readings of Islamist violence, 'Islam' does ultimately emerge as other" in his novel (2011: 479). Similarly, Samuel Thomas claims that Terrorist "ends up reinscribing many of the ideological patterns ... that it at least seeks to interrogate, if not debunk" (2011: 442). The concordance output

Othman, A. A. M. (2019). Fundamentalist and tolerant islamic discourse in john updike's terrorist and jonathan wright's translation the televangelist: a corpus-based critical discourse analysis of semantic prosody. International Journal of Linguistics, Literature and Culture, 5(6), 1-27. https://doi.org/10.21744/ijllc.v5n6.747 
reinforces this claim because the negative attitude created by Updike does not distinguish between fundamentalist and tolerant Islam. Rather, it stigmatizes Islam as a whole as a superstitious and violent religion.

In Wright's The Televangelist, however, the keyword Islam has a defensive semantic prosody as the following concordance lines show: It co-occurs with nodes like: condemns this cowardly terrorism, allegations propagated by the opponents of, knows how to defend, understood the facts of, what he says about is really bad and offensive, won't be upset by the offensive things he says about, apart from what you've heard from sheikhs, or from priests on the Internet insulting, when you lash out and attack, I don't represent.

you and from the other eminent sheikhs about how ISLaM condems this cowardly terrorism. In fact, as soo uld only have been comitted by someone who hated ISLMM and knew nothing about it, and that on the Day of es and to enlighten the nation by explaining that ISLAM was not responsible for murders by the faithless he sins comitted by terrorists and attributed to ISL MM, a religion that, through its tolerance and compa these allegations propagated by the opponents of ISLAM, this skepticism about the integrity of the Proph slim who is well educated and knows how to defend ISLAM is not afraid of questions and does not tremble $i$ our genius insight you've understood the facts of ISLMM and the essence of Chriatianity? That arrogance $i$ ristian. He's studied hard and what he says about ISLAM is really bad and offensive." As they said goodby e at the door, Hatem said, "To be honest, doctor, ISLAM won't be upset by the offensive things he says ab our genius insight you've understood the facts of ISLAM and the essence of Christianity? That arrogance $i$ ristian. He's studied hard and what he says about ISLAM is really bad and offensive." As they said goodby e at the door, Hatem said, "To be honest, doctor, ISLAM won't be upset by the offensive things he says ab he says about it or even by his decision to quit ISLM, but I feel gorry for the kid leaving Islan and and you can only be familiar with ten percent of ISLAM, apart from what pou're heard from sheikhs or fro sheikhs or from priests on the Internet insulting ISLAM. And besides, you can't understand Christianity $w$ $t$ you ought to know, when you lash out and attack ISLMM or even Christianity, that no one can really mast s of a religion. Now as for me, I don't represent ISLAM, of course, and that's the nicest thing about itit. You' re free in your relationship with God in ISLAM and in Christianity too, because the clerics have errible state. In that sense, it is a disgrace to ISLAM. If you want to confine the umma to the however $m$ ot interested in what books or who you've read on ISLaM but I'm asking what you've read about Christianit may have most of the flaws that you don't like in ISLAM, for example, or maybe all religions are a big tr sheikhs and priests, arguing about many things in ISLMM and Christianity," Tadros replied. "We came to th ,

\section{Figure 13. Islam in Wright's Televangelist}

The co-text of Islam, therefore, conveys the writer's defensive attitude. Like the original novelist, the translator has assumed the responsibility of defending Islam against all the attacks and allegations of the West that associate it with terrorism and violence.

In Updike's Terrorist, the keyword prophet has an unfavourable semantic prosody. Prophet Mohammed is described as too supernatural to believe as is shown in the following concordance lines:

returning to Earth, to become the last of the PROFHETs, the ultimate one. His adventures that day are p
He never claimed to be God; he was just God's PROFHET. The only miracle he ever claimed was the Qur'an
inner devil murmurs. What evidence beyond the PROPHET's blazing and divinely inspired words proves that
says that these visionary descriptions by the PRPHET are figurative. They are truly about the burning
re. Our deeds and thoughts were written in the PROPHET's consciousness in letters of gold, like the burn
injunction to pray five times a day, which the PROHET brought back to Earth after the night journey on
Creator, al-Khdliq. The imagery of words, the PROFHET knew, alone grips the soul with its own spiritual
rnally pre-existed in Paradise, to which the PROPHET during one night-journey travelled on the supernatural Buraq

Figure 14. Prophet in Updike's Terrorist

The keyword prophet, which refers to Prophet Mohammed, co-occurs with ultimate, adventures, miracle, perfect, blazing and divinely inspired words, visionary descriptions, in letters of gold, brought back to Earth after the night journey, grips the soul with its own spiritual, during one night-journey travelled on the supernatural horse Buraq.

In Wright's The Televangelist, however, the keyword prophet has a favourable semantic prosody: 
and second, that Kuhammad ibn Abdullah was both a prophet and a human being, in other words there is a huma these are his feelings as a human being, not as a prophet, first because he wanted Zeinab for himself, seco t came from being famous. He surpassed the other prophets in physical and moral qualities Nor did they ap more reason to have doubts than abraham. Yes, the prophet abraham doubted, yes, the father of all prophets e prophet abraham doubted, yes, the father of all prophets doubted the pover of God and maybe also the exis wasn't it a feature of the early martyrs and the prophets that they put up with ridicule from their enemies nt twenty-three years carrying out his mission as prophet without teaching his companions, talking with the hese things about the Companions and wives of the prophet, and insulted them in this horrible way, why shou

\section{Figure 15. Prophet in Wright's Televangelist}

It co-occurs with human being, wanted Zeinab for himself, voice, physical and moral qualities, doubted, put up with ridicule from their enemies, mission, teaching his companions, Companions and wives. Thus the prophet is described as human with physical and moral qualities.

In Updike's Terrorist, the keyword Quran has an unfavourable semantic prosody as is shown in the following concordance lines:

kh Rashid, the imam. We study together the sacred Qur'an." Levy tries to suppress his distaste, saying, "Y his third-floor spaces, a kuttab for teaching the Qur'an to flocks of elementary-school-age children, hang nberg, who maintains that many obscurities of the Qur'an disappear if the words are read not as hrabic but s slyness about him, implying at moments that the Qur'an may not have eternally pre-existed in Paradise, $t$ along a truck route in New Jersey, he quotes the Qur'an: "God giveth you life, then causeth you to die: $t$ astise me, I fear. Now that I work, I neglect the Qur'an, and my Friday attendance has fallen off, though S that they, the devils, have a voice in the Holy Qur'an-are doubting the resurrection of the body, which innocent? Unbelievers say that. God says, in the Qur'an, Be ruthless to unbelievers. Burn them, crush the

\section{Figure 16. Qur'an in Updike's Terrorist}

It co-occurs with flocks of elementary-school-age children, many obscurities of, may not have eternally pre-existed in Paradise, a shell of violent shorthand, causeth you to die, neglect, the devils, have a voice in, be ruthless to unbelievers. This negative attitude towards the Holy Qur'an together with the incredulity surrounding Prophet Mohammed's miracles reinforce the anti-Islamic discourse in Updike's novel.

In Wright's The Televangelist, on the other hand, the keyword Qur'an has a very positive semantic prosody as is obvious from the following concordance lines:

hed. Hatem spoke with such solemity, recited the Quran so eloquently, and was so quich with sayings of t 're not a sheikh, then what are you? You know the guran by heart and you know how to recite it, you lead is recited from high above the seven heavens, the Quran, by which we will worship until the day when peop er shameful. Polls, would the comentators on the Quran have singled out this verse for all this explanat story. On the contrary, we can be proud that the Quran has taught us to be completely transparent about in the Prophet's household it becomes part of the Quran by which we worship when we pray. A strong Muslim places, he understood that line of the miraculous Quran: We gave orders to the toms folk who live in luxu "No, it's not us who say that. That's in the Holy Quran. That's God personally saying it, but what exact 1 ired it remained believers or never rebelled. The Quran schools produced ulema who served their communities

Figure 17. Qur'an in Wright's Televangelist

It co-occurs with eloquently, by heart and you know how to recite it, had memorized the whole, is recited from high above the seven heavens, we can be proud, as taught us to be completely transparent, by which we worship when we pray, the miraculous, Holy, schools produced ulema who served their communities. This veneration of the Holy Qur'an is characteristic of pro-Islamic discourse.

As for the keyword Shaikh in Updike's Terrorist, it has an unfavourable semantic prosody as appears from the following concordance lines:

Othman, A. A. M. (2019). Fundamentalist and tolerant islamic discourse in john updike's terrorist and jonathan wright's translation the televangelist: a corpus-based critical discourse analysis of semantic prosody. International Journal of Linguistics, Literature and Culture, 5(6), 1-27. https://doi.org/10.21744/ijllc.v5n6.747 
in the luncheonette of a small-city airport, the shaikh admonishes, "g, h: two distinct sounds, not "sh." fades, leaving on his face a crust of unease. The shaikh has closed his eyes again in g to the kafir church ting word." The cell phone that lives deep in the shaikh's overlapping garments suddenly sounds its trilli see $a$ guilty incomprehension on Ahmad's face, the shaikh, with his thin off-center smile, translates: " A , so seductively, in a recess of facial haix. The shaikh was not wearing his turban or his lacy white amdm I- proves to be lulling, reassuring him, when the shaikh at last left him alone, that this room is indeed f soporific gas. He was not comfortable under the shaikh"s concerned gaze, and wished now the man would go ing ugly, a digfiguring little twigt, crossed the shaikh"g clean-shaven face. WitJiout his beard and richl distance to it by now, a receding vibration. The shaikh went on, "In 2 war, if the soldier beside you the lost, the already dead, at Central High? The shaikh was hurried and troubled, yet had difficulty in 1 kh Rashid would have disapproved. Last night, the shaikh seemed troubled, something was pressing on him he ir brains in a rhydimical rapture as illusory as (Shaikh Rashid sardonically puts forward the analogy) the ng old Jew, and guards as well his suspicion that Shaikh Rashid is so furiously absolute in his doctrines mon. They were both about professional assassins. Shaikh Rashid is right- movies are sinful and stupid. Th back in." Now, with somewhat the same testy tone, Shaikh Rashid answers, "They don"t want you to drive out the marks of this decadent and rootless society. Shaikh Rashid-a man slight and slim as a dagger, with a d know that, too. His teacher at the mosque, this Shaikh Rashid, is kind of creepy; but Ahmad's axare. He

\section{Figure 18. Shaikh in Updike's Terrorist}

Shaikh co-occurs with negative words such as: admonishes, leaving on his face a crust of unease, with his thin offcenter smile, in a recess of facial hair, at last left him alone, concerned gaze, ugly, a disfiguring little twist, in a war, if the soldier beside you falls, hurried and troubled, seemed troubled, something was pressing on him, sardonically puts forward the analogy, is so furiously absolute in his doctrines, his master has few disciples, indolently concedes, provocative moods, satiric, movies are sinful and stupid, testy tone, a man slight and slim as a dagger, is kind of creepy, dry, half-smiling allusions, has come sharply out of his trance. Islamic sheikhs are thus stereotyped as ugly and dubious. Again Updike's description of the dubious Shaikh Rashid who controls Ahmed is generalized to all Islamic sheikhs and thus creates an anti-Islamic attitude.

Although the keyword Sheikh has an unfavourable semantic prosody in Wright's Televangelist, Islamic sheikhs are stereotyped as gluttonous and materialistic as in the following concordance lines:

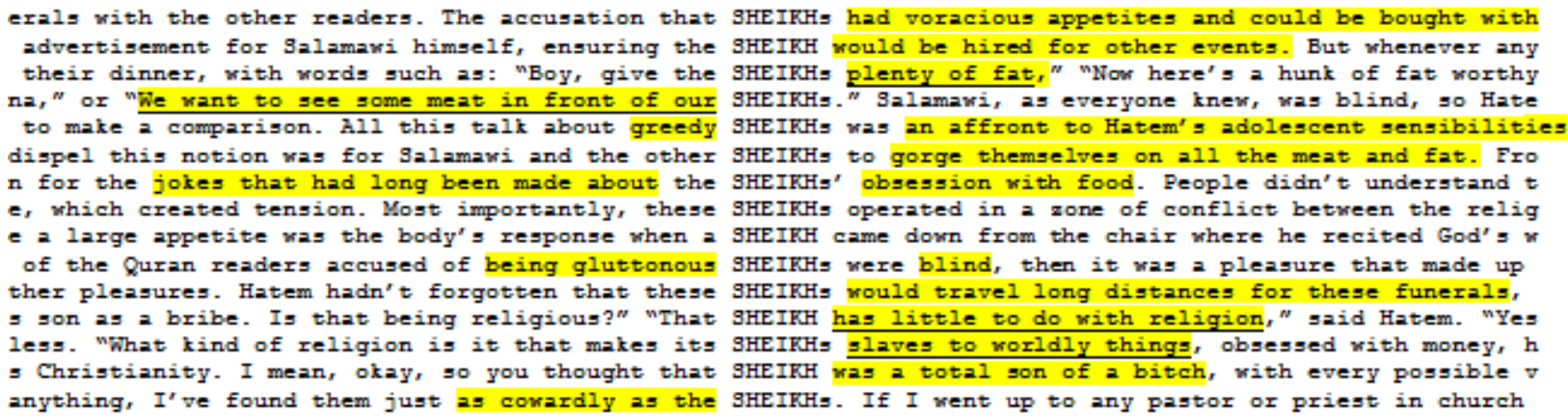

\section{Figure 19. Sheikh in Wright's Televangelist}

Sheikh co-occurs with nodes that emphasize the stereotypical image of gluttony such as: had voracious appetites and could be bought with, plenty of fat, we want to see some meat in front of our, greedy, waiting for their dinner, gorge themselves on all the meat and fat, jokes that had long been made about obsession with food, being gluttonous, who would never say no to a good dinner. As for sheikhs' materialism, it is emphasized through the co-text of closer to them than to God, coming to earn a few pennies, would be hired for other events, would travel long distances for these funerals, lived in a mansion and owned cars and spent money, who tried to flatter and curry favor, who took religion into the world of adolescents, tries to please the customer, showing off his watch on his right hand, the Arzaqia (opportunists). The keyword Imam, however, has a favourable semantic prosody in Wright's The Televangelist as appears from the following concordance lines: It co-occurs with the works of recognized, active in the early years of Islam, prominent, the great, who codified Islamic law after them, and led the people in dawn prayer, and he seemed proud to be among the, inside the historic mosque where he worked as, who is a very important, to have security clearances, his book is a major reference, of the pious, may God be pleased with him, say it belongs to the twelve, who were grand themselves, the legal precepts of, the coming of the long-awaited, After declaring allegiance to, who looked happy that the Grand, was treating him with such honor. 


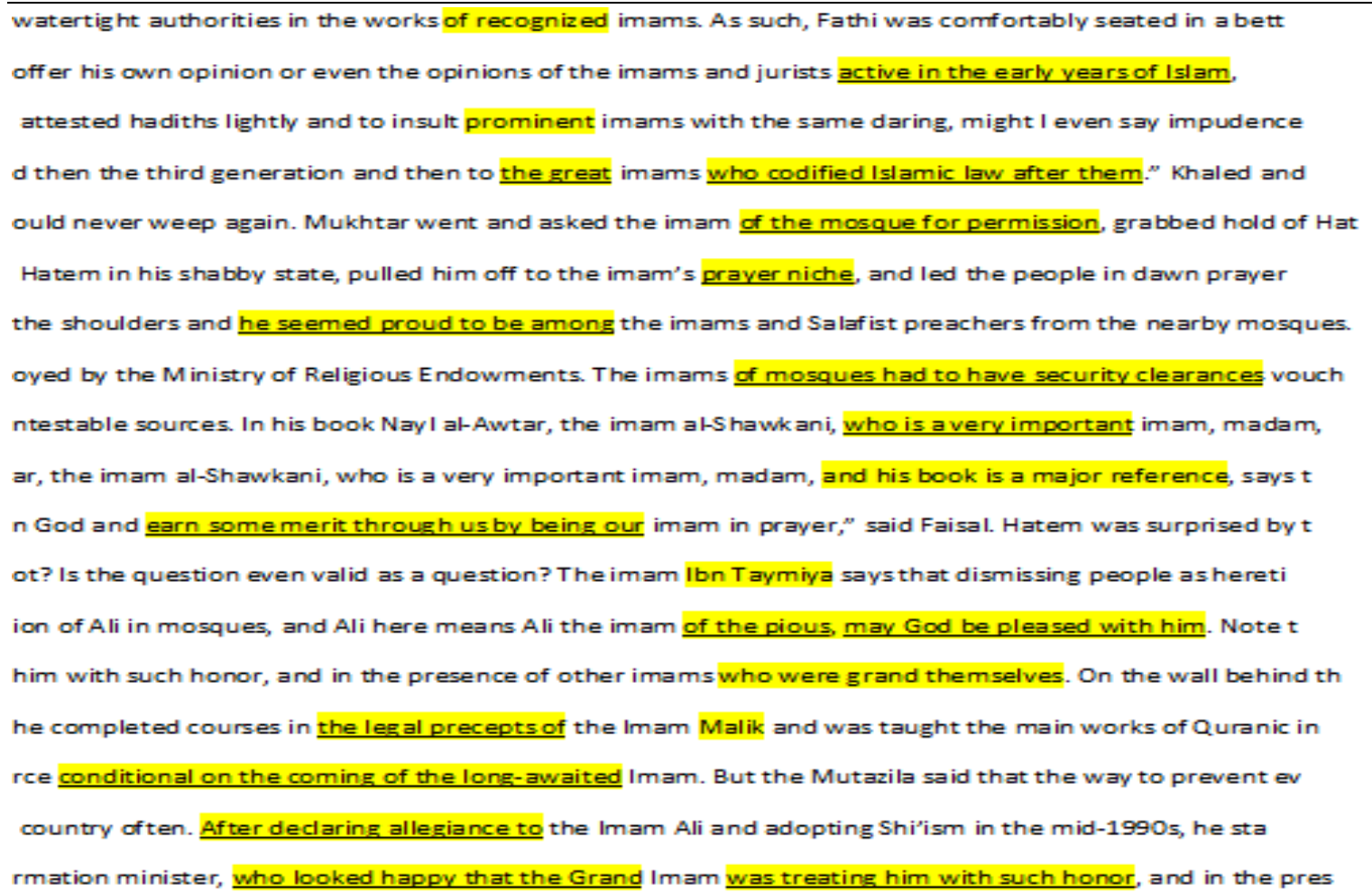

Figure 20. Imam in Wright's Televangelist

Unlike sheikh which is a title of respect for religious and unreligious persons, the word imam refers to the person who leads prayers in a mosque and is used as a title of various Muslim leaders. This difference in use explains the difference in the semantic prosody that shades the meaning of the two words. Whereas sheikhs are stereotyped as greedy and materialistic, imams are venerated and respected.

In Updike's Terrorist, on the other hand, the keyword imam has an unfavourable semantic prosody as appears from the following concordance lines: It co-occurs with casts down his eyes, which are an unexpectedly pale gray, as milky and elusive as a kafir woman's, the devils gnawing within him tinges the imam's voice, of this hard-to-find place, helped you to waste your high-school years, a stern-faced, coffee-colored man with wireless glasses and a flashing tall bald head, showed a short temper with his pupil, presented half a face, the lower half being hidden, almost never came out to say hello, His black shoes, tiny and obdurate as a child's, twangs out a twist of Arabic as if sticking a dagger into the silent audience, a slight, impeccable man embodying a belief system that not many years ago managed the deaths of, the man in his white garb sticks like a bone in the throat of the occasion, drive a truck, it's an idea he picked up from his, with an impatience that bites off his words as precisely as his beard is trimmed, would tell me was blasphemy, deserving an eternity of Hellfire, rhetoric, delivered by a two-edged voice that seems to withdraw even as it proffers, shuts his eyes again as in a holy trance, looked down upon him, the hidden, with his featureless face.

Othman, A. A. M. (2019). Fundamentalist and tolerant islamic discourse in john updike's terrorist and jonathan wright's translation the televangelist: a corpus-based critical discourse analysis of semantic prosody. International Journal of Linguistics, Literature and Culture, 5(6), 1-27. https://doi.org/10.21744/ijllc.v5n6.747 


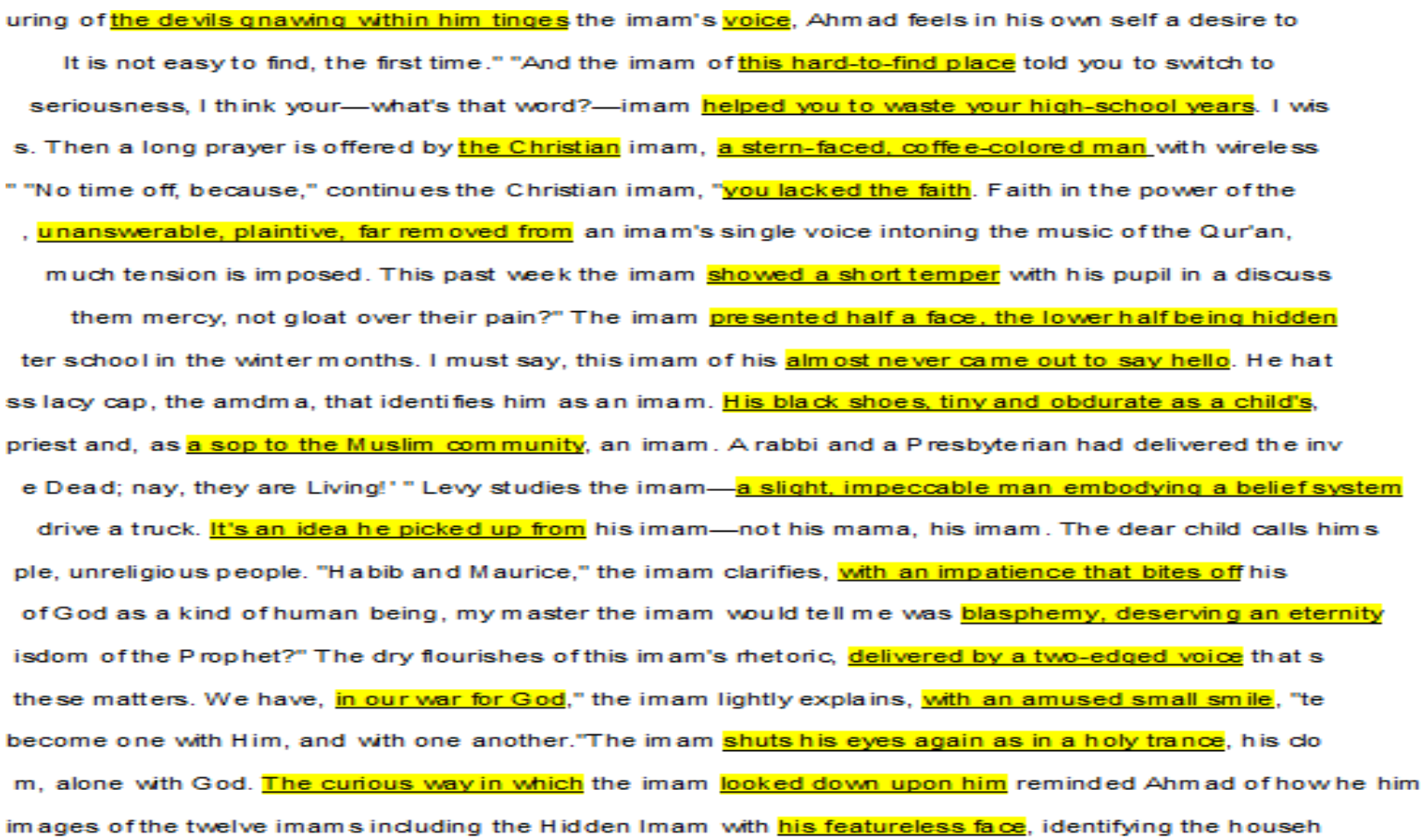

\section{Figure 21. Imam in Updike's Terrorist}

In Updike's Terrorist, therefore, there is no distinction between sheikhs and Imams because the anti-Islamic discourse draws them both in an unfavourable light.

Likewise, the keyword preacher has an unfavourable semantic prosody: it co-occurs with ascends into the high minbar decorated, the chuckles that greet this revelation, and heated crowd of dark-skinned knffar, in his blue bigsleeved robe, taken off guard, hurries on, consulting his big Bible again, blue sleeves thrash and bits of spittle, slumps in the pulpit a little wearily, is proclaiming in a voice roughened by oratory, is not quite done with them, decides the time to close has come, didn't take none of the man's shit.

$\mathrm{n}$, concerning the joys of walking with Jesus, the preacher ascends into the high minbar decorated xith car bove the chuckles that greet this revelation, the preacher goes on, "That way, I xould be saving my voice. tant and heated crowd of dark-skinned knffar, the preacher is musing to himself, having forgotten why he $i$ ot in the midst of die children of Israel.' "The preacher, in his blue big-sleeved robe with a shirt and who knows." Nobody does, taken off guard, and the preacher hurries on, consulting his big Bible again, tug crow or sxallow, a seagull or a coxbird." Now the preacher's blue sleeves thrash and bits of spittle from glory for a change. I want your carcasses.' "The preacher slumps in the pulpit a little wearily, and reat treasure she has spotted xithin him. "Paith," the preacher is proclaiming in a voice roughened by oratory, in Ahmad's pex has gleaming cheeks, he sees. The preacher is not quite done with them. "The Lord of who?" heba." "The Lord of Zipporah," calls a third. The preacher decides the time to close has come. "The Lord o black classmates concerning their mosques, their preachers who "didn't take none of the man's shit." Othe Figure 22. Preacher in Updike's Terrorist

Fundamentalists view Christian preachers as unbelievers and ridicule their oratory. Of special effect is dismissing the Christian names of objects and describing them in Islamic terms like "the high minbar."

In Wright's The Televangelist, however, the keyword preacher has a positive semantic prosody, but it refers only to Islamic scholars. It co-occurs with who gave fatwas was a man like them, in a government-run mosque, and Islamic scholar, who didn't look like sheikhs, other well-known television, and even the stars of television serials, a television star, appointed to the big mosque, goes up in the pulpit every Friday, and Quran reader at funerals, people 
who admire, charismatic, and melodious voices, seemed proud to be among the imams and Salafist from the nearby mosques, the historic mosque where he worked as imam, had probably been monitoring him, employed by the Ministry of Religious Endowments, monitored the mosque and the, who appear on this amazing box, people see me as modern, like the young, who wear suits and shirts, and being a scholar, You're the young people's, the most famous, from the satellite channels.

Hatem could see, they approved of the fact that a preacher who gave fatwas was a man like them, a man who rting out in the media. At the time he was only a preacher in a government-run mosque but he had caught th allment of our program. Today we have with us the preacher and Islamic scholar, his grace sheikh Hatem e1ndermine Sheikh Fathi's privileged position-those preachers who didn't look like sheikhs, who took religio ell aware that he and other well-known television preachers, and even the stars of television serials, mig ansform you from a sheikh into a producer, from a preacher to a television gtar. There were dues he would I to you?" asked Hatem in desperation. "A mogque preacher and a television evangelist." "Very well, that ${ }^{\prime}$ er of Religious Endowments gave orders that a new preacher be appointed to the big mosque where our ancest osque where our ancestors are buried, and the new preacher goes up in the pulpit every Friday, Monday, and pretty much a child, and at the same time I was a preacher and Quran reader at funerals. Anyone who has ex ly of religious people but of people who admire a preacher's voice, even if they don't pay much attention ects of religion and were cray about charismatic preachers and melodious voices that could move the liste e seemed proud to be among the imams and Salafist preachers from the nearby mosques. The noise was unbeara e the historic mosque where he worked as imam and preacher, in case it became too crowded and the building se off, out of boredom, so $\mathrm{it}^{\prime} \mathrm{s}$ important for the preacher to keep people awake. But that doesn't mean sho , had probably been monitoring him since he was a preacher employed by the Kinistry of Religious Endoments ole area oversaw and monitored the mogque and the preacher. But when Hatem moved into the world of televis Wuslims stand above everyone and that our tagk as preachers who appear on this amaring box, this world sta I turbanspeople see me as modern, like the young preachers who wear suits and shirts and who act all reve ack. "Why do you switch so eagily between being a preacher and being a scholar?" she asked. "I'm a Rifai a I powers of persuasion. You're the young people's preacher, Mawlana. But tell me, can I tell the big man t d abandoned me. The great sheikh, the most famous preacher in the country, had become a crasy dervish. You day doing his dirty work. hll the evangelists and preachers from the satellite channels, and the Balafist

\section{Figure 23. Preacher in Wright's Televangelist}

In Updike's Terrorist, the keyword mosque has a negative semantic prosody. It co-occurs with do I know where, I fear I don't, was a domain of men, all unbelievers are our enemies, that would not do, writing the check for $\$ 89.50$, Omar never went, this terrible teacher at, put him up to it, exploration of his Islamic identity ends at, the humblest of the several in New Prospect, took him in as a child of eleven, on the second floor, to get this boy out of the grip of, they're like Baptist fundamentalists, shabby and fragile, friends as powerful as they are pious, so frail and scared when I'd drop him off, going up those stairs all by himself after three months of skipping his lessons, the nail salon below, whose windows have a view of only brick walls, license to drive a truck because the imam had asked him to.

Othman, A. A. M. (2019). Fundamentalist and tolerant islamic discourse in john updike's terrorist and jonathan wright's translation the televangelist: a corpus-based critical discourse analysis of semantic prosody. International Journal of Linguistics, Literature and Culture, 5(6), 1-27. https://doi.org/10.21744/ijllc.v5n6.747 
s his distaste, saying, "Yes. Do I know where the mosque is? I fear I don't, except for the huge one on Ti movie theatre before the movie starts than a holy mosque, with its thick muffling rugs and empty tiled mih ogether as closely as the segments of a worm. The mosque was a domain of men; here, women in their spring didn't have no enemies there." "My teacher at the mosque says that all unbelievers are our enemies. The Pr came to my church," she says. "I could go to your mosque with you." "That would not do. We could not sit $t$ gan for them, writing the check for $\$ 89.50$ on the mosque account. Ahmad always thought truck-driving was s not much more to his father. Omar never went to a mosque that I could see, and whenever I'd try to raise t $y$ intuition tells me this terrible teacher at the mosque put him up to it." "Speaking of terri-ble," Jack $\mathrm{m}$, 2 s if he is a white girl with pretty legs. The mosque, the humblest of the several in New Prospect, occ s exploration of his Islamic identity ends at the mosque. The mosque took him in as a child of eleven; it n of his Islamic identity ends at the mosque. The mosque took him in $2 s$ a child of eleven; it let him be b -ager and relatively safe on the streets, to this mosque on the second floor. The large hall converted to imself out to get this boy out of the grip of his mosque. They're like Baptist fundamentalists, only worse hmad, "Appearances can deceive. Though I know our mosque appears, to youthful eyes, shabby and fragile in lt upon truths set deep in the hearts of men. The mosque has friends, friends as powerful as they are pious so frail and scared when I'd drop him off at the mosque, going up those stairs all by himself. When I'd a e told me, it's hard for him to always get to the mosque on Fridays, and this Charlie who's always with hi ut I think I'd know that, too. His teacher at the mosque, this Shaikh Rashid, is kind of creepy; but ahmad after three months of skipping his lessons at the mosque, deciphers the quote in the head and ponders it $f$ er, the imam from Yemen. The nail salon below the mosque, though well equipped with chairs, holds one bore rted here, in the closed space of this inner-city mosque, whose windows have 2 view of only brick walls an license to drive a truck because the imam at his mosque had asked him to?" "Vaguely. Jack hasn't mentioned

Figure 24. Mosque in Updike's Terrorist

The co-text of mosque imparts this feeling of fear and mistrust. This negative attitude towards mosques, the places of worship in Islam, can be said to stem from the more general Islamophobia and mistrust of Muslims in the West.

In Wright's The Televangelist, however, the keyword mosque has a highly positive semantic prosody. In contrast to the mosques in Updike's Terrorist, which are portrayed as small and shabby, mosques here are described as grand, well-known places of learning and worship. The co-text includes nodes like: who came to hear his sermon in the Sultan Hassan, they filled every inch, which could hold several thousand people, would fill up and people recorded his sermons, of the most important local saints, whole delegation went through the square, the Hussein, el-Sayeda Zeinab, el-Rifai, the Sultan Hassan, big, where our ancestors are buried, where your father was the Sufi leader, the minaret of, in the oldest, that belongs to the Ministry of Religious Endowments, surrounded by warm welcomes from sheikhs and other people who were praying, lavished money and sympathy on the poor and servants, purged himself of pride and anger by cleaning the toilets, historic, a growing number of admirers and his remote, what required by the etiquette of sitting in, a gathering place, had to have security clearances, for the whole area oversaw and monitored, donate the land and have, and a Quran school built on it, gets bigger and bigger and the minaret goes up, verses of the Quran inscribed along the walls, at al-Azhar were giving their lessons in the courtyard, seated at the base of a column. 
who came to hear his sermon in the Sultan Hassan mosque every Friday were ordinary people too, and they f ary people too, and they filled every inch of the mosque, which could hold several thousand people, not co e time he was only a preacher in a government-run mosque but he had caught the attention of congregants th ngregants through the quality of his sermons. The mosque would fill up and people recorded his sermons on a building overlooking the main square, near the mosque of the most important local saints. After a fex m e whole delegation went through the square to the mosque, the scene marked Abu Hadid in the consciousness what am I to you?" asked Hatem in desperation. "h mosque preacher and a television evangelist." "Very well themselves and to others. He went to the Hussein mosque but didn't go inside. He spent twenty-two days in $n$ the restrooms there, or in the restrooms at the mosques of el-3ayeda Zeinab, el-Rifai, the Sultan Hassan rders that a new preacher be appointed to the big mosque where our ancestors are buried, and the new preac hould be in charge of the mosque. Imagine! In the mosque where your father was the Sufi leader, a preacher $y$ heard things like that from the minaret of that mosque. That led to big confrontations between the local 't stop all the bile spilling out. "In the oldest mosque in the province, which was built more than a hund ground because it's about to fall down. This is a mosque that belongs to the Ministry of Religious Endowments take Hatem off in his car to pray in the Hussein mosque or in the Bayeda Nafisa mosque. Months passed and ure does," said Hatem, "because the sheikh in the mosque tries to please God, while the television sheikh in person that he loved Him. He went to the Rifai mosque and performed the sunset prayer, surrounded by wa nset prayer, surrounded by warm welcomes from the mosque sheikhs and other people who were praying. He lav e lavished money and sympathy on the poor and the mosque servants, then set off on foot to his father's ho purged himself of pride and anger by cleaning the mosque toilets had given him some strength and taken axa had married Omayma when he was an imam in a small mosque run by the ministry, and the term 'small' applied - him as much as to the mosque. It was a historic mosque but dilapidated, large but in a sparsely populate - see him. After the congregation came out of the mosque, he would shake hands with the people waiting aro uired a growing number of admirers and his remote mosque started to get crowded. He began to receive invit 's what required by the etiquette of sitting in a mosque, while a mosque is also called 'a gathering place by the etiquette of sitting in a mosque, while a mosque is also called 'a gathering place.' In other word he Ministry of Religious Endorments. The imams of mosques had to have security clearances vouching for the an with a plain-clothes policeman assigned to the mosque, and if the mosque was important it would be assi thes policeman assigned to the mosque, and if the mosque was important it would be assigned to the officer icer for the whole area oversaw and monitored the mosque and the preacher. But when Hatem moved into the $w$ rty he then decides to donate the land and have $a$ mosque and $a$ Quran school built on it. People in the tor ited to contribute to the building costs, and the mosque gets bigger and bigger and the minaret goes up an uses, and verses of the Quran inscribed along the mosque walls. The church, on the other hand, is very aus means that he led people in prayer, preached in a mosque, and taught in a school. In fact he and some frie hers at al-hahar were giving their lessons in the mosque courtyard, seated at the base of a column, did th

\section{Figure 25. Mosque in Wright's Televangelist}

Mosques are thus described as sacred places where family members of the prophet are buried and where sermons are given to large numbers of people. Imams of such mosques have security clearances to make sure they do not belong to any terrorist groups.

Like mosques, the keyword prayer has an unfavourable semantic prosody in Updike's Terrorist. It co-occurs with long, offered by the Christian imam, the chorus is chanting the one word, the organist is bouncing up and down, just the five calls to, broadcast over a still slide of the great mosque, take it to the Lord, fussily, rug on the floor, its woven-in mihrab, the mock-mihrab in its abstract pattern.

d out, and to whom he can turn at every moment in prayer. God is his happiness. This old Jevigh devil, ben he Lord is thankd for that and this. Then a long prayer is offered by the Chrietian imam, atern-faced, her the chorus is chanting the one word, "Prayer, prayer, prayer." The organist is bouncing up and down, Marhattan and Jersey City just the five calls to prayer broadeat ower a still slide of the great mosque ar in conclusion. ". . . take it to the Lord in prajer." "He watehe her briakly put her clothes back o d's ritul ablutions. Eussily, he pointed out the prayer rug on the Eloor, its woven-in mihrab giving the a nuber of pieces of ardbord. He prays on the praper rug, the mockmihrab in its abstact pattern orie Figure 26. Prayer in Updike's Terrorist

Fundamentalist Islamic discourse thus criticizes Christian prayers for the music element in them and refuses to even learn the names of sacred places in the church. This is significant because even though Ahmed has American citizenship and a Christian mother, he still uses words like the Christian imam and mock-mihrab, thus emphasizing his rejection of assimilation and alienation from what he views as.

Othman, A. A. M. (2019). Fundamentalist and tolerant islamic discourse in john updike's terrorist and jonathan wright's translation the televangelist: a corpus-based critical discourse analysis of semantic prosody. International Journal of Linguistics, Literature and Culture, 5(6), 1-27. https://doi.org/10.21744/ijllc.v5n6.747 
In Wright's The Televangelist, on the other hand, the keyword prayer has a positive semantic prosody. It cooccurs with all those people you lead in, your disciples, the people who ask you for fatwa, and give sermons, and raised his string of amber beads to his chest, asked him to grace him with a, he had proudly been fingering his, to sing a, raised the spirits of the audience, who was welcoming and attentive, in a sentimental tone, pulled him off to the imam's niche, and woke him up to perform together in el-Hussein or Sayeda Zeinab, everyone stood behind him to perform the evening, holding his beads in both hands, instead he said a silent, at dawn they would perform the usual, together and then he would say a special, in the distance the muezzin gave the dawn call to, marks on their foreheads.

of Hatem's program. "All those people you lead in prayer, your disciples, the people who ask you for fatwa and you know how to recite it, you lead people in prayer and give sermons, you've memorized fatwas and you aned his head back and raised his string of amber prayer beads to his chest. He checked that the red light lagt elections and agked him to grase him with a prayer, and the sheikh told him he was going to win the $f$ the generals. He had proudly been fingering his prayer beads with an audible clicking throughout the ses ect, so he asked for Sheikh Baid Sorour to sing a prayer, since by then he had had his fill of food and ha cried: "O God, 0 God, Our Lord the Prophet." The prayer raiged the gpirits of the audience and gome of th other, who was welcoming and attentive and said a prayer for him in a sentimental tone. Hatem knew that th in his shaby state, pulled him off to the ims's prayer niche, and led the people in davn prayers. After $\mathrm{m}_{r}$ who was aleep, and woke him up to perform the prayer together in el-Husein or Bayed zeinab. If Hatem Everyone stood behind him to perform the evening prayer, which he had in fact performed before he even an $e^{\prime \prime}$ he quoted. Hatem leaned forward, holding his prayer beads in both hands. "Wane' here means to fade, ew it was a deadly trap. Instead he said a silent prayer to God. "Of ourse you're going to ask why we tho ot together. At dawn they would perform the usual prayer together and then he would say a special prayer $f$ In the distance the muerrin gave the dawn call to prayer, possibly through the radio of one of the securit ms in the world it's only those in Egypt who have prayer marks on their foreheads? Is it some genetic feat

\section{Figure 27. Prayer in Wright's Televangelist}

Thus prayers in The Televangelist refer only to Islamic prayers which bring Muslims closer to God and unit them when performed in congregation.

In Updike's Terrorist, the keyword Muslim has an unfavourable semantic prosody: It co-occurs with: We were getting hate calls, Anti-, did you set out to raise him as, as a sop to, he thinks he's. Updike here reflects the mistrust and hate of Muslims in the West especially after 9/11. Again he does not differentiate between fundamentalists and tolerant Muslims and hence he reinforces Islamophobia.

tle breathless. "We were getting hate calls. Anti-Kuslim. I had the number changed and unlisted, even if i be so-so good? Did you set out to raise him as a Kuslim?" "No, Christ," she says, dragging deep, playing offered by a Catholie priest and, as a sop to the Kuslim conmunity, an imam. A rabil and a Presbyterian ha h gchool Jack has been adriging. He think he's a Mulim becauge hig deadbeat father was, at the game time Figure 28. Muslim in Updike's Terrorist

In contrast, the keyword Muslim has a favourable semantic prosody in Wright's The Televangelist: it co-occurs with well-educated, strong, knowledgeable, devout and worshipped God, must accept God's rulings obediently, don't debate God's injuctions, His greatness has compassion for all of humanity, have to fulfill particular obligations, the privileges given to, pious, inventors and explorers, free from slavery to anything and anyone other than God, scholars, save their country from chaos, believe in the light of the Virgin, who pray, develop a mark on their foreheads. 
all I'd like to affirm two truths: firgt, that a Muslim who is well educated and knows how to defend Islan guran by which we worship when we pray. A strong Muslim is a knowledgeable Muslim, and a weak Muslim, anx rong Muslim is a knowledgeable Muslim, and a weak Muslim, Anwar, is a Muslim who is ignorant." The phanton ammad and the Mother of the Believers, told other Muslin women, who were devout and worshiped God, that th d it word for word. The ulema have taught us that Muslims must accept God's rulings obediently. When a mat rong path. That's what Islam means, Sheikh Hatem. Muslims don't debate God's injunctions. They debate the course, any verse in the Quran? In this case the Muslim gind has to get to work, and this mind changes ov beyond reading children's stories? So anyway, the Muslim mind has to ask itself a number of questions and h and poor, corrupt people and honest people, not Muslims and Christians, but to make sure that the poor o His greatness has compassion for all of humanity-Muslims, Christians, Jews, atheists, Buddhists, bastards sense that they don't get the privileges given to Muslims. Besides, your criticism of Islam, that it says The truth is that anyone who cones in here-pious Muslin, sheikh in a turban, Buddhist monk, Companion of $n$ 'You' re the best uma' is conditional on 2 duty Muslims have to fulfill, particular obligations that the ecline. And besides, in the Middle Ages, when the Muslins were the inventors and explorers, they were the ustice, and equality. One of the aims was to free Muslims from slavery to anything and anyone other than God $r$ only in the things he told us to do? "The early Muslin scholars"-he took a long look at Nashwa-"differed the love of security and stability, because true Muslims want to save their country from chaos, and obedi tart off with, that the Sunna and the pious early Muslims atand above everyone and that our tash as preach want to make fun of Hassan's confugion. "So what? Muslins believe in the light of the Virgin as well as Ch stion. "What do you mean, Mawlana?" he said. "All Muslims who pray develop a mark on their foreheads from

\section{Figure 29. Muslim in Wright's Televangelist}

In tolerant Islamic discourse, Muslims are described as worshippers of God and followers of His orders. They have no prejudices against other religions and, like Christians, they believe in the light of the Virgin.

Regarding the keyword Christian, it has an unfavourable semantic prosody in the fundamentalists' discourse in Updike's Terrorist as appears from the following concordance lines:

coming closer by millimeters. The teachers, weak Christians and nonobservant Jexs, make a show of teaching $\mathrm{v}$ ry the school teaches, pure colonialist. Look hox Christianity committed genocide on the Native hmericans and leepless geeks, even those of Caucasian blood and Christian upbringing. When the heaven splits asunder in the 1s, even seated, dizzily, blasphemously tall. The Christian attitude of lazily sitting erect as at an enterta e the curious carvings on what he takes to be the Christian equivalent of the minbar slowly sort themselves 0 ipe organ that he spies gathering dust beyond the Christian minbar. All stand to sing. Ahmad is brought to hi at and this. Then a long prayer is offered by the Christian imam, a stern-faced, coffee-colored man with wire end! Evil!" "No time off, because," continues the Christian imam, "you lacked the faith. Faith in the porer o 5. The mosque and its teachers give them what the Christian 0.3 . disdains to- respect, and a challenge that a perialist economic system rigged in favor of rich Christians. Mr. Levy, hearing his surly tone, asks, "Do you ence and simple mechanisms of the Greeks when all Christian Europe had in its barbarism forgotten such things s and airplanes and roadside bombs. Islam, unlike Christianity, has no fear of scientific truth. allah had fo 11 yood and a ruthless economic imperialism whose Christian-Jexish God is a decrepit idol, a mere mask concea Figure 30. Christian in Updike's Terrorist

It co-occurs with weak, committed genocide, attitude of lazily sitting erect as at an entertainment, disdains respect, barbarism, fear of scientific truth, God is a decrepit idol. Most remarkable is the ironic use of "Christian minbar" instead of pulpit and "Christian imam" instead of priest or preacher. The fundamentalists' antagonistic attitude towards Christians is thus used to criticize Islam in general in Updike's anti-Islamic discourse.

In sharp contrast, the keyword Christian has a positive semantic prosody in tolerant Islamic discourse in Wright's The Televangelist as is demonstrated by the following concordance lines:

Othman, A. A. M. (2019). Fundamentalist and tolerant islamic discourse in john updike's terrorist and jonathan wright's translation the televangelist: a corpus-based critical discourse analysis of semantic prosody. International Journal of Linguistics, Literature and Culture, 5(6), 1-27. https://doi.org/10.21744/ijllc.v5n6.747 
tness has compassion for all of humanity-Muslins, Christians, Jews, atheists, Buddhists, bastards, and sons of don't believe, until the Day of Besurrection. The Christians aren't infidels or polytheists. Not only that, bu " Hatem continued, "I' a against trying to convert Christians to Islam, on the sharia principle that preventing hear a Muslin talking about his friendships with Christians, or a Christian talking about his Muslin friends. required to prove the $y^{\prime}$ re not prejudiced against Christians, or because the $\eta^{\prime}$ re Christian that the $y^{\prime}$ re suppos and understood and are convinced about. Even the Christians who convert to Islam in Egypt operate on the basi oject the same simplicity and spirituality as the Christians themselves. "And I bet you that on the inside the Sheikh Ali Badr for permission to try to convert Christians to Islam and to debate with them. Sheikh Ali Badr pression: 'We are bound by pronises not to harass Christians and Jews.' He was worried his disciple might beco 7 should all make clear to Egyptians, Muslins and Christians alike, when they addressed the whole world in the

\section{Figure 31. Christian in Wright's Televangelist}

The keyword Christian co-occurs with positive nodes like: has compassion for all humanity, aren't infidels or polytheists, I'm against trying to convert, a Muslim talking about his friendship with, they're not prejudiced against, the same simplicity and spirituality, we're bound by promises not to harass, alike. Wright's establishment of a consistently positive semantic prosody for Christians characterizes his tolerant Islamic discourse which call for accepting the other and extending compassion to all humanity.

With regards to the keyword convert, it has a favourable semantic prosody in Updike's Terrorist: it co-occurs with as enunciated by the Prophet, like Elizabeth Taylor, to worship, her son's sacrifice may perhaps persuade her to, maybe you could.

purpose, as enunciated by the Prophet, be to convert the infidels? In any case, shouldn't He show them

Jew, and my wife was a Lutheran." "Was? Did she convert, like Eliz abeth Taylor?" Jack Levy snarls out a c

this mosque on the second floor. The large hall converted to worship was once a dance studio, and the ima

her son's sacrifice may perhaps persuade her to convert. All things are possible with Allah." "My mother-

having a serious conversation, maybe you could convert me, except there are all these baggy hot clotb.es

Figure 32. Convert in Updike's Terrorist

One of the basic tenets of fundamentalists is to convert followers of other religions to Islam. Having created this positive semantic prosody for conversion, Updike uses it to criticize Islam in general because he does not draw a line between fundamentalists and tolerant Muslims who accept others.

In Wright's Televangelist, however, the keyword convert has an unfavourable semantic prosody: It co-occurs with negative expressions such as: Hatem almost wet himself, a apostate from Islam, it would destroy all the good, accused of trying to, leaked by the organizations or people who, that would threaten a family, a spoiled brat who thinks it's a game, was confused rather than determined to, mistaken, destroy the country, in protest, I'm against trying to, ignorant kids tricked into, I don't want to, relished provoking the complacent, those in authority, they seemed very weak and fragile. Of special significance is Sheikh Hatem's Ironic remark to Hassan, who pretended to have converted to Christianity: "I am really not losing any sleep because you've converted." Objection to conversion when it is not based on true learning and conviction is made clear through the consistently negative semantic prosody in the following concordance lines: 


\footnotetext{
kh Hatem with doleful eyes. "No," she said. "He's converted to Christianity." Hatem almost wet himself. He wife's brother was an apostate from Islam and a convert to Christianity. It would destroy all the good th $y$ arrested some groups they accused of trying to convert people to Christianity and they launched a securi ht be leaked by the organiz ations or people who converted him to Christianity. That would threaten a family you're iust a spoiled brat who thinks it's a game converting to Christianity, then PII be happy to see the Hassan was confused rather than determined to convert. (In fact he thought that Hassan might not even $r$ act he thought that Hassan might not even really convert but was only using the possibility that he might stians become Muslims but you don't want us to convert Muslims to Christianity?" "The truth is I don't w pinion," Hatem continued, "l'm against trying to convert Christians to Islam, on the sharia principle that doing something beneficial. If Muslims think that converting a Christian to Islam serves islam they are mistaken

"Ym really not losing any sleep because you've converted to Christianity. You can be sure I don't spend e crazy and think they're prophets. They want to convert everyone and destroy the country." "Brigadier," $\mathrm{H}$ Iblis himself. You're free, and I dor't want to convert you back to Islam anyway. I want to get you back fighting those in authority. Hatem felt they had converted in protest, the ultimate protest, or in order $t$ veng eful attention from the despotic. The young converts relighed provoking the complacent, those in authority , you think we're just ignorant kids tricked into converting to Christianity, and you see yourself as theo pretending to be brave martyrs determined to convert. They seemed very weak and fragile and in need of
}

\section{Figure 33. Convert in Wright's Televangelist}

As for fundamentalists' negative attitude towards women, it is obvious in Updike's Terrorist in the negative semantic prosody of the keywords woman and women: the singular noun co-occurs with as milky and elusive as a kafir, a whale of, deep creases, a fat older, a skinny one the color of dried leadier, skinny dried-up, fat, drooping over her shoes, the very fat, should serve a man, shaky, impropriety and possible mockery, aging, sucking the life out of, dirty anyway, has ditched me.

ctedly pale gray, as milky and elusive as a kafir woman's, and says that these visionary descriptions by pider in the center. His wife, Beth, a whale of a woman giving off too much heat through her blubber, bre 10, but she stays in her row, between a fat older woman and a skinny one the color of dried leadier, all tations and trouble anywhere. The skinny dried-up woman next to Joryleen steps forkard and, in a voice th for-horsake thee?" "Hey, well, do they?" the fat woman next to her calls out, chiming in as if Joryleen' not pure. The singing, especially of the very fat woman"" "Eva-Yarie," Joryleen supplies. "She's the most to this fount of xisdom? Does he consider you his woman?" "Oh, that boy's just trying things out. He's to Beth's weight has had twenty more years than this woman's to settle low, drooping over her shoes and taki 5 if I was pushing in where I had no business. 'A woman should serve a man, not try to own him, he'd say laid-back as she wants to appear, this is a shaky woman, who married what her harp brothers and father wo ugh to disown his mother. Conscious merely of the woman's impropriety and possible mockery, the man snatc n her legs, for fear of Beth's smelling the other woman through their good-night kiss-a mere peck, but th 've been abandoned and single in the best years a woman is supposed to have. Nox I'm forty. Don't begrudg Arabia Deserta. Ahmad sees his mother as an aging woman still in her heart a girl, playing at art and lov keep maneuvering, you just punch. Dealing with a woman is like jujitsu, looking for the trip. She senses or not even closed behind them. He liked having a woman on the side. He liked her baggage: her being a mo on Beth, too. Sucking, sucking the life out of a woman, drag- ging her down into your feeling so sorry $f$ ng. Allah can blame me. I can take it, I'm just a woman, dirty anyway. "Joryleen puts her hands one on ea ucking face, for all I care. Why should I care? a woman I was crazy about has ditched me, my job is a dra Figure 34. Woman in Updike's Terrorist

Othman, A. A. M. (2019). Fundamentalist and tolerant islamic discourse in john updike's terrorist and jonathan wright's translation the televangelist: a corpus-based critical discourse analysis of semantic prosody. International Journal of Linguistics, Literature and Culture, 5(6), 1-27. https://doi.org/10.21744/ijllc.v5n6.747 
Thus women are viewed by fundamentalists as merely sex objects. Similarly, the plural, women, has a negative semantic prosody in Updike's Terrorist: It co-occurs with purses were sinkholes of confusion and sedimented treasure, massive, do without, non-Heavenly flesh, this earthly baggage, uncleanness, their menstruation, their suckling of infants, a pollution, separate yourselves therefore from, approach them not, until they be cleansed, nakedness, withdrew into wrinkles and a proud shapelessness, sex enhancement, the monstrous buttocks of, the fat black, bouncing and rolling with an intensity, oppression of, animals easily led, boring, his fields.

for Women's Purses. The problem was real enough: women's purses were sinkholes of confusion and sedimented een in the choir, a mass of mostly women, massive women among whom Joryleen looks girlishly young and rel e massaging him. He likes it, up to a point, when women start undressing their minds in front of him. But d safaba, abstain and turn axay! Do without these vomen of non-Heavenly flesh, this earthly baggage, thes n. It talked of uncleanness but only in regard to women, their menstruation, their suckling of infants. I meet $\mathrm{Him}$. In the verse before that, he read that women are a pollution. Separate yourselves therefore fr e a pollution. Separate yourselves therefore from women and approach them not, until they be cleansed. Bu $s$ and, the Book emphasizes, children who note not romen's nakedness. As a child often or less, he more th untries of the Mediterranean and the Middle East, women withdrex into wrinkles and a proud shapelessness; of her, yet speaks of women often, especially the romen who appear on television commercials. "Did you se men sag hugely and the monstrous buttocks of die women seesax painfully as tiiey tread the boardxalk in ospel choruses in iridescent robes, the fat black romen bouncing and rolling with an intensity that at ti e above your mother. I cannot say that I approve: women are our fields, but our mother is the Earth itsel e already has a boyfriend, a notorious "bad" one. Women are animals easily led, khmad has been warned by Leaving before he gets bored suits him, actually. Women can be boring. They make everything personal. The Figure 35. Women in Updike's Terrorist

This misogynistic attitude towards women is typical of fundamentalist Islamic discourse that always speaks of women as unclean, inferior sex objects.

In Wright's The Televangelist, however, the keywords woman and women have a positive semantic prosody:

half-naked young man appeared and an irresigtible woman sauntered up to him, took a deep breath, and let t he didn't have a noble pedigree while she was a woman of high rank and good farily. This can happen eve ary secret." "As you say, sir." A mowent later, a woman in her late thirties appeared, wearing a dress th " She sat down quietly, in a way that suggested a woman who was well brought up. It seemed to be time for ehind the hijab and the loose shirt, a sexy young woman might be hiding. Omajna took her leave on sone no ied it might sound too harsh for such a sensitive woman. "Given that Hassan says he's a Chrigtian and has buried in the cushion. He saw an exhausted young woman preoccupied by thoughts nuch too weighty for her pertise the role of a strict and comitted Muslin woman who also happened to be in a foul mood, managed $t$ e must have made a mistake: it was a fully veiled woman draped in blach from head to foot. The only part he came quichly too. What virility! Of course the woman might be his wife, so why would people think he $x$ t overwhelened him but from the deceit of a pretty woman he had thought was his angel, sent to bring him In

\section{Figure 36. Woman in Wright's Televangelist}

Woman co-occurs with irresistible, of high rank and good family, in her late thirties, a sexy young, a sensitive, an exhausted young, a strict and committed Muslim, a fully veiled, draped in black from head to foot, might be his wife, a pretty, he had thought was his angel.

Similarly, the plural, women, has a positive semantic prosody in Wright's The Televangelist:

-shinned, beautiful, and buxom, one of the finest women of the Quraysh, and he fell for her and said, 'Pr nd the Mother of the Believers, told other Muslim women, who were devout and worshiped God, that they sho I've seen several Iranian films in which all the women wear the hijab and even so the films were like ma sure how to answer. "You look confused. Look, all wonen are pretty but there are different types of prett nt, and what's your master's on?" "The freedon of women in Islan, a study of the practice of the Prophet, gious requirement, but there's nothing wrong with wonen wearing the niqab, since the $y^{\prime}$ re free to interpre 7. It's the real hijab. In fact God Almighty told women to stay at home and not to go out in the first pl so obliging that I'd say anything like that-that women should stay at home. And what do you mean, stay 2 percent of the fanilies are supported by working women, not counting the fifty percent of households whe Figure 37. Women in Wright's Televangelist 
It co-occurs with one of the finest, devout and worshipped God, wear the hijab, are pretty, the freedom of, wearing the niqab, stay at home, families are supported by working. Tolerant Islamic discourse in Wright's translated novel thus emphasizes women's freedom, chastity, beauty and protection.

\section{Results and Discussions}

To begin with, the topics or global meanings of the two novels are expressed in the title. The title of Updike's novel refers to the protagonist, Ahmed, the would-be terrorist. Since Ahmed is a Muslim name, the first association the reader makes is between Islam and terrorism. It follows that the overall topic of the text is Islamic terrorism. This global meaning is reinforced through the negative semantic prosody of Islamic keywords: God, faith, belief, religion, Islam, prophet, Qur'an, sheikh, imam, preacher, mosque, prayer, Muslims, Christians \& women. The text is thus polarized at both the global and local levels. In other words, there is a consistent strategy of "negative other presentation," and the other in this case is Islam and Muslims who are misrepresented throughout the text. The result is that the reader generalizes the fundamentalist Islamic discourse and equates Islam with terrorism, animosity, intolerance \& backwardness. In addition to the dominant fundamentalist Islamic discourse, there is a parallel antiIslamic discourse that criticizes Islam, Prophet Mohammed and the Qur'an, ridicules Islamic scholars, sheikhs and Imams, and misrepresents mosques, Islamic prayers and Muslims. In contrast, the title of Wright's translated novel refers to the tolerant Sheikh Hatem, who occupies the center of attention throughout the novel since he was the Imam of Sultan Hassan, the historic mosque, until he became a famous televangelist. At the global level, therefore, the topic of Wright's translation is Islamic tolerance. This global meaning is emphasized through the positive semantic prosody of the same Islamic keywords: God, faith, belief, religion, Islam, prophet, Qur'an, sheikh, imam, preacher, mosque, prayer, Muslims, Christians \& women. Characteristic of this tolerant Islamic discourse is veneration of God, Islam and Prophet Mohammed, glorification of the Holy Qur'an, respect of mosques, preachers and women, and acceptance of followers of other religions.

\section{Conclusion}

To conclude, the analysis of the semantic prosody of thematic signal keywords in the two novels selected for comparison shows that there is a significant difference between Updike's Terrorist and Wright's The Televangelist in terms of Islamic discourse. While Islamic discourse is essentially fundamentalist in Updike's novel, it is highly tolerant in Wright's. Van Dijk's proposition of the polarized representation of 'us' versus 'them' holds for Updike's novel which negatively represents Islam and Muslims by establishing a consistently negative semantic prosody for Islamic keywords and making fundamentalist discourse stand for all Islamic discourse. However, Van Dijk's proposition holds only partially for Wright's The Televangelist which creates a positive semantic prosody for Islamic keywords, thus positively representing Islam and Muslims, without misrepresenting the other. These results encourage researchers to combine CDA and Corpus Linguistics in the analysis of Literature to understand literary men's attitude towards the issues discussed in their literary works.

Conflict of interest statement

The author declared that (s)he has no competing interest.

Statement of authorship

The author has responsibility for the conception and design of the study. The author has approved the final article.

Acknowledgments

The author would like to thank the editor of IJLLC for their valuable time, support and advice.

Othman, A. A. M. (2019). Fundamentalist and tolerant islamic discourse in john updike's terrorist and jonathan wright's translation the televangelist: a corpus-based critical discourse analysis of semantic prosody. International Journal of Linguistics, Literature and Culture, 5(6), 1-27. https://doi.org/10.21744/ijllc.v5n6.747 


\section{References}

Abid, R. Z., \& Manan, S. A. (2015). Integrating corpus linguistics in critical literacy pedagogy: A case study of Lance Armstrong's transformation from a titleholder to a fraud. Procedia-Social and Behavioral Sciences, 208, 128-137. https://doi.org/10.1016/j.sbspro.2015.11.189

Archer, D. (Ed.). (2009). What's in a word-list?: investigating word frequency and keyword extraction. Ashgate Publishing, Ltd..

Augoustinos, M., \& Every, D. (2010). Accusations and denials of racism: Managing moral accountability in public discourse. https://doi.org/10.1177/0957926509360650

Azhari, A. S., Priono, -, \& Nuriadi, -. (2018). Speech Acts of Classroom Interaction. International Journal of Linguistics, Literature and Culture, 4(2), 24-45.

Baker, P., Gabrielatos, C., Khosravinik, M., Krzyżanowski, M., McEnery, T., \& Wodak, R. (2008). A useful methodological synergy? Combining critical discourse analysis and corpus linguistics to examine discourses of refugees and asylum seekers in the UK press. Discourse \& society, 19(3), 273-306. https://doi.org/10.1177\%2F0957926508088962

Chiluwa, I. (2012). Online religion in Nigeria: The internet church and cyber miracles. Journal of Asian and African Studies, 47(6), 734-749.

Downs, G. W., \& Jones, M. A. (2002). Reputation, compliance, and international law. The Journal of Legal Studies, 31(S1), S95-S114.

Edwards, M., \& Milani, T. M. (2014). The everyday life of sexual politics: A feminist critical discourse analysis of herbalist pamphlets in Johannesburg. Southern African Linguistics and Applied Language Studies, 32(4), 461481. https://doi.org/10.2989/16073614.2014.999991

Essa, I. (2016). The Televangelist. (J. Wright, Trans.). Cairo: AUC Press.

Fitri, -, Mahyuni, -, \& Sudirman, -. (2018). Schematic of humorous discourse of stand-up comedy in Indonesia. International Journal of Social Sciences and Humanities, 2(3), 107-116. https://doi.org/10.29332/ijssh.v2n3.213

Flowerdew, J., \& Miller, L. (1997). The teaching of academic listening comprehension and the question of authenticity. English for specific purposes, 16(1), 27-46. https://doi.org/10.1016/S0889-4906(96)00030-0

Freake, R., Gentil, G., \& Sheyholislami, J. (2011). A bilingual corpus-assisted discourse study of the construction of nationhood and belonging in Quebec. Discourse \& Society, 22(1), 21-47. https://doi.org/10.1177\%2F0957926510382842

Hardt-Mautner, G. (1995). " Only Connect": Critical Discourse Analysis and Corpus Linguistics. Lancaster: UCREL.

Hartnell, A. (2011). Violence and the Faithful in Post-9/11 America: Updike's Terrorist, Islam, and the Specter of Exceptionalism. MFS Modern Fiction Studies, 57(3), 477-502. https://doi.org/10.1353/mfs.2011.0066

Henry, F., \& Tator, C. (2002). Discourses of domination: Racial bias in the Canadian English-language press. University of Toronto Press.

Hunston, S. (2007). Semantic prosody revisited. International journal of corpus linguistics, 12(2), 249-268. https://doi.org/10.1075/ijcl.12.2.09hun

Huntington, S. P. (1993). The Clash of Civilizations? Foreign Affairs 72.

Iswanto, -, Riana, I. K., Simpen, I. W., \& Ola, S. S. (2018). Supernatural signification system amuf on death ritual speech nen fen nahat neu nitu in boti society. International Journal of Linguistics, Literature and Culture, 4(2), 46-57.

Jackson, R. (2007). Constructing enemies:'Islamic terrorism'in political and academic discourse. Government and Opposition, 42(3), 394-426. https://doi.org/10.1111/j.1477-7053.2007.00229.x

Jaworska, S., \& Krishnamurthy, R. (2012). On the F word: A corpus-based analysis of the media representation of feminism in British and German press discourse, 1990-2009. Discourse \& Society, 23(4), 401-431. https://doi.org/10.1177\%2F0957926512441113

Jeffries, L., \& Evans, M. (2013). The rise of choice as an absolute 'good': a study of British manifestos (19002010). SRC Working Papers, 5, 1-24.

Jurgaitis, N. (2018). Economic crisis as a supernatural being in public discourse. International Journal of Linguistics, Literature and Culture, 4(2), 66-71.

Kawangung, Y. (2019). Religious moderation discourse in plurality of social harmony in Indonesia. International Journal of Social Sciences and Humanities, 3(1), 160-170. https://doi.org/10.29332/ijssh.v3n1.277 
KhosraviNik, M. (2008). British newspapers and the representations of refugees, asylum seekers and immigrants between 1996 and 2006.

Lindayana, -, Arifuddin, -, \& Mandala, H. (2018). Divergent Principles of Politeness in Verbal and Non-Verbal Directive Speech Act. International Research Journal of Engineering, IT \& Scientific Research, 4(2), 41-51.

Lippi, M., \& Torroni, P. (2016). Argumentation mining: State of the art and emerging trends. ACM Transactions on Internet Technology (TOIT), 16(2), 10. https://doi.org/10.1145/2850417

Louw, B. (1993). Irony in the text or insincerity in the writer? The diagnostic potential of semantic prosodies. Text and technology: In honour of John Sinclair, 240, 251.

Louw, B. (2000). Contextual prosodic theory: Bringing semantic prosodies to life. Words in context: A tribute to John Sinclair on his retirement, 48-94.

MacDonald, M. N., \& Hunter, D. (2013). Security, Population and Governmentality: UK Counter-terrorism Discourse (2007-2011). Critical Approaches to Discourse Analysis Across Disciplines, 7(1).

Mahlberg, M., \& McIntyre, D. (2011). A case for corpus stylistics. English Text Construction, 4(2), $204-227$. https://doi.org/10.1075/etc.4.2.03mah

Morrison, A., \& Love, A. (1996). A discourse of disillusionment: Letters to the editor in two Zimbabwean magazines 10 years after independence. Discourse \& Society, 7(1), $\quad 39-75$. https://doi.org/10.1177\%2F0957926596007001003

Mulderrig, J. (2008). Using keywords analysis in CDA: Evolving discourses of the knowledge economy in education. In Education and the knowledge-based economy in Europe (pp. 147-169). Brill Sense. https://doi.org/10.1163/9789087906245 009

Mulderrig, J. (2011). Manufacturing Consent: A corpus-based critical discourse analysis of New Labour's educational governance. Educational Philosophy and Theory, 43(6), 562-578. https://doi.org/10.1111/j.14695812.2010.00723.x

Murphy, P. E. (2013). Tourism: A community approach (RLE Tourism). Routledge.

Nartey, M., \& Mwinlaaru, I. N. (2019). Towards a decade of synergizing corpus linguistics and critical discourse analysis: A meta-analysis. Corpora: corpus-based language learning, language processing and linguistics. http://dx.doi.org/10.3366\%2Fcor.2019.0169

Nartey, M., \& Mwinlaaru, I. N. (2019). Towards a decade of synergizing corpus linguistics and critical discourse analysis: A meta-analysis. Corpora: corpus-based language learning, language processing and linguistics. http://dx.doi.org/10.3366\%2Fcor.2019.0169

O'Halloran, K. L. (2008). Systemic functional-multimodal discourse analysis (SF-MDA): Constructing ideational meaning using language and visual imagery. Visual communication, 7(4), 443-475. https://doi.org/10.1177\%2F1470357208096210

Partington, A. (2004). " Utterly content in each other's company" Semantic prosody and semantic preference. International journal of corpus linguistics, 9(1). https://doi.org/10.1075/ijcl.9.1.07par

Pearce, D. (2014). Blueprint 3: Measuring sustainable development. Routledge.

Prasetyo, H. (2017). Euphemism in oral dialect speech ngeto-ngete district suralaga. International Journal of Linguistics, Literature and Culture, 3(1), 65-74.

Prentice, S., \& Hardie, A. (2009). Empowerment and disempowerment in the Glencairn Uprising: A corpus-based critical analysis of Early Modern English news discourse. Journal of Historical Pragmatics, 10(1), $23-55$. https://doi.org/10.1075/jhp.10.1.03pre

Schröter, M., \& Storjohann, P. (2015). Patterns of discourse semantics: A corpus-assisted study of financial crisis in British newspaper discourse in 2009. Pragmatics and Society, 6(1), 43-66. https://doi.org/10.1075/ps.6.1.03sch

Simon-Vandenbergen, A. M. (2000). The functions of I think in political discourse. International Journal of Applied Linguistics, 10(1), 41-63. https://doi.org/10.1111/j.1473-4192.2000.tb00139.x

Sinclair, J. (2004). Trust the text. In Trust the text (pp. 19-33). Routledge.

Sinclair, J. M. (1996). The Search for Units of Meaning'. Textus IX: 75-106. Reprinted in lohn Sinclair (2004) Trust the Text: Language, Corpus and Discourse.

Skalicky, S. (2013). Was this analysis helpful? A genre analysis of the Amazon. com discourse community and its "most helpful" product reviews. Discourse, Context \& $\quad$ Media, 2(2), 84-93. https://doi.org/10.1016/j.dcm.2013.04.001

Sotillo, S. M., \& Starace-Nastasi, D. (1999). Political discourse of a working-class town. Discourse \& Society, 10(2), 249-276. https://doi.org/10.1177\%2F0957926599010002006

Othman, A. A. M. (2019). Fundamentalist and tolerant islamic discourse in john updike's terrorist and jonathan wright's translation the televangelist: a corpus-based critical discourse analysis of semantic prosody. International Journal of Linguistics, Literature and Culture, 5(6), 1-27. https://doi.org/10.21744/ijllc.v5n6.747 
Spencer, H. (2011). Semantic Prosody in Literary Analysis: A Corpus-based Stylistic Study of HP Lovecraft's stories (Doctoral dissertation, University of Huddersfield).

Subtirelu, N. (2013). What (do) learners want (?): a re-examination of the issue of learner preferences regarding the use of 'native'speaker norms in English language teaching. Language Awareness, 22(3), 270-291. https://doi.org/10.1080/09658416.2012.713967

Suyanu, -, Rusdiawan, -, \& Sumerep, A. Z. (2017). The use of language elements in the creation of coherences in discourse. International Journal of Linguistics, Literature and Culture, 3(5), 101-108.

Taylor, T. L. (2009). Play between worlds: Exploring online game culture. Mit Press.

Thomas, S. (2011). Outtakes and Outrage: The Means and Ends of Suicide Terror. MFS Modern Fiction Studies, 57(3), 425-449. https://doi.org/10.1353/mfs.2011.0062

Törnberg, A., \& Törnberg, P. (2016). Muslims in social media discourse: Combining topic modeling and critical discourse analysis. Discourse, Context \& Media, 13, 132-142. https://doi.org/10.1016/j.dcm.2016.04.003

Triebl, E. (2015). ... or not to be. The Strategic and Non-Strategic Use of Negative Identifiers in Online Forums. AAA: Arbeiten aus Anglistik und Amerikanistik, 247-270.

Van Dijk, T. A. (1993). Elite discourse and racism (Vol. 6). Sage.

Van Dijk, T. A. (1995). Discourse semantics and ideology. Discourse \& society, 6(2), 243-289. https://doi.org/10.1177\%2F0957926595006002006

Van Dijk, T. A. (2001). 18 Critical discourse analysis. The handbook of discourse analysis, 349-371.

Van Dijk, T. A. (2001). Multidisciplinary CDA: A plea for diversity. Methods of critical discourse analysis, 1, 95120.

Wodak, R., \& Meyer, M. (2009). Critical discourse analysis: History, agenda, theory and methodology. Methods of critical discourse analysis, 2, 1-33.

Wodak, R., \& Meyer, M. (2009). Critical discourse analysis: History, agenda, theory and methodology. Methods of critical discourse analysis, 2, 1-33.

\section{Biography of Author}

\begin{tabular}{|l|l|l|}
\hline \hline & $\begin{array}{l}\text { Dr. Ahlam Othman is an Associate Professor of English Language \& Literature and } \\
\text { Quality Assurance Unit Director at the Faculty of Arts \& Humanities. She has a Ph.D. } \\
\text { in English Comparative Literature from Al-Azhar University and two MA degrees: one } \\
\text { in English Literature from Al-Azhar University and the other in TEFL from the AUC. } \\
\text { Dr. Othman's research interests are English Comparative Literature, Literary } \\
\text { Translation, Corpus Linguistics, and Curriculum Development. She is a board member } \\
\text { of the Egyptian Society of Comparative Literature, a member of the Translation } \\
\text { Division at the Egyptian Writers' Federation and editor of Muqaranat, an annual } \\
\text { journal. Dr. Othman gave teacher training on: "Teachers' Beliefs and SLA Theories,", } \\
\text { "Teaching Methodology," "How to Write a Lesson Plan," "Multiple Intelligences and } \\
\text { Differentiated Instruction," and "Classroom Management." In addition, she conducted } \\
\text { several staff development workshops including: "Creating Interactive Videos Using } \\
\text { Educanon," "The Effect of Corpus-based DDL activities on the Development of } \\
\text { Academic Writing," \& "Karaoke in the English Language Classroom." } \\
\text { Email: ahlam.othman@bue.edu.eg }\end{array}$ \\
\hline
\end{tabular}


Appendix A

\begin{tabular}{|c|c|c|c|c|c|c|c|c|c|}
\hline \multirow[t]{2}{*}{$\#$} & \multirow[t]{2}{*}{ Keyword } & \multicolumn{2}{|c|}{ Rank } & \multicolumn{2}{|c|}{ Frequency } & \multicolumn{2}{|c|}{ Key } & \multicolumn{2}{|c|}{ Effect } \\
\hline & & Televangelist & Terrorist & Televangelist & Terrorist & Televangelist & Terrorist & Televangelist & Terrorist \\
\hline 1 & God & 183 & 590 & 419 & 174 & 736.37 & 211.89 & 0.0002 & 0.0001 \\
\hline 2 & Faith & 328 & 32 & 22 & 51 & 485.56 & 1180.06 & 0.0003 & 0.001 \\
\hline 3 & Believers & 1000 & & 5 & & 110.35 & & 0.0001 & \\
\hline 4 & Unbeliever & & 373 & & 13 & & 300.79 & & 0.0003 \\
\hline 5 & Believe & 431 & 1611 & 16 & 4 & 353.13 & 92.55 & 0.0002 & 0.0001 \\
\hline 6 & Religion & 20 & 141 & 163 & 22 & 3597.7 & 509.04 & 0.002 & 0.0005 \\
\hline 7 & Islam & 12 & 110 & 217 & 25 & 4789.65 & 578.45 & 0.0026 & 0.0005 \\
\hline 8 & Prophet & 9 & 42 & 258 & 42 & 5694.67 & 971.81 & 0.0031 & 0.0009 \\
\hline 9 & Qur'an & 23 & 40 & 150 & 45 & 3310.76 & 1041.23 & 0.0018 & 0.0009 \\
\hline $\begin{array}{l}1 \\
0 \\
\end{array}$ & $\begin{array}{l}\text { Sheikh/ } \\
\text { Shaikh }\end{array}$ & 2 & 21 & 522 & 77 & 11522.61 & 1781.68 & 0.0063 & 0.0016 \\
\hline $\begin{array}{l}1 \\
1 \\
\end{array}$ & Imam & 424 & 63 & 19 & 34 & 419.35 & 786.7 & 0.0002 & 0.0007 \\
\hline $\begin{array}{l}1 \\
2\end{array}$ & Preacher & 206 & 318 & 31 & 14 & 684.2 & 323.93 & 0.0004 & 0.0003 \\
\hline $\begin{array}{l}1 \\
3\end{array}$ & Mosque & 58 & 69 & 79 & 33 & 1743.63 & 763.56 & 0.0009 & 0.0007 \\
\hline $\begin{array}{l}1 \\
4\end{array}$ & Prayer & 138 & 207 & 41 & 18 & 904.91 & 416.49 & 0.0005 & 0.0004 \\
\hline $\begin{array}{l}1 \\
5\end{array}$ & Muslims & 43 & 348 & 100 & 13 & 2207.14 & 300.79 & 0.0012 & 0.0003 \\
\hline $\begin{array}{l}1 \\
6\end{array}$ & Christians & 73 & 160 & 67 & 20 & 1478.77 & 462.76 & 0.0008 & 0.0004 \\
\hline $\begin{array}{l}1 \\
7\end{array}$ & Convert & 128 & 1670 & 42 & 4 & 926.99 & 92.55 & 0.0005 & 0.0001 \\
\hline $\begin{array}{l}1 \\
8\end{array}$ & Woman & 48 & 36 & 92 & 48 & 2030.57 & 1110.64 & 0.0011 & 0.001 \\
\hline
\end{tabular}

Othman, A. A. M. (2019). Fundamentalist and tolerant islamic discourse in john updike's terrorist and jonathan wright's translation the televangelist: a corpus-based critical discourse analysis of semantic prosody. International Journal of Linguistics, Literature and Culture, 5(6), 1-27. https://doi.org/10.21744/ijllc.v5n6.747 